\title{
THE SOCIAL CONTEXT OF COMPENSATION DESIGN: SOCIAL NORMS AND THE IMPACT OF EQUITY INCENTIVES
}

\author{
Leon Zolotoy \\ Melbourne Business School, University of Melbourne \\ 200 Leicester Street, Carlton, VIC 3053 \\ Australia \\ $\mathrm{Ph}:+61393498424$ \\ Email:1.zolotoy@mbs.edu \\ Don O'Sullivan* \\ Melbourne Business School, University of Melbourne \\ 200 Leicester Street, CarltonVIC 3053 \\ Australia \\ $\mathrm{Ph}:+613934998223$ \\ Email: d.osullivan@mbs.edu \\ Geoffrey P. Martin \\ Melbourne Business School, University of Melbourne \\ 200 Leicester Street, Carlton, VIC 3053 \\ Australia \\ $\mathrm{Ph}:+61393498400$ \\ Email: g.martin@mbs.edu
}

*Corresponding author

$\underline{\text { Keywords: }}$ CEO compensation, institutional theory, social networks

This is the author manuscript accepted for publication and has undergone full peer review but has not been through the copyediting, typesetting, pagination and proofreading process, which may lead to differences between this version and the Version of Record. Please cite this article as doi: $10.1002 / \mathrm{hrm} .21897$

This article is protected by copyright. All rights reserved. 
Leon Zolotoy is an Associate Professor of Finance at Melbourne Business School. He earned his $\mathrm{PhD}$ from Tilburg University at Tilburg, Netherlands. His research focuses, primarily, on two themes: (i) mechanisms through which information disseminates among investors and impounded in stock prices and (ii) executive compensation designs and their impact on CEO decision making. Leon's research interests include asset pricing, executive compensation, corporate governance, and behavioural finance.

Don O'Sullivan is an Associate Professor in Marketing at Melbourne Business School. Don earned his $\mathrm{PhD}$ from the National University of Ireland (Cork). His principal academic interests are in strategic marketing, executive compensation and risk taking and the relationship between reputation and firm performance.

Geoff Martin is an Associate Professor of Strategy at Melbourne Business School and earned his $\mathrm{PhD}$ from IE Business School in Madrid, Spain. His research has explored governance mechanisms intended to mitigate agency problems in the context of CEO decision making and family firms. Geoff's research interests include executive compensation, strategic risk taking, corporate governance and family business. 


\title{
THE SOCIAL CONTEXT OF COMPENSATION DESIGN: SOCIAL NORMS AND THE IMPACT OF EQUITY INCENTIVES
}

\begin{abstract}
Drawing on arguments from institutional theory, this study examines how social normsspecifically, local religious social norms — affect the motivational impact of equity-based incentives. We test our model using longitudinal data on local religious norms, CEO equity incentives and firm value. Consistent with our theoretical predictions, we find that local religious social norms attenuate the impact of CEO option incentives upon firm value. Furthermore, we find that the attenuating impact of local religious social norms increases with managerial discretion. These findings provide valuable insight for human resource professionals aiming to design compensation contracts for employees that are aligned with firm goals. Our findings also contribute to research on the motivational effect of equity incentives by demonstrating importance of considering the social context in which executives are embedded.
\end{abstract}

Keywords: CEO compensation, institutional theory, social networks

This article is protected by copyright. All rights reserved. 


\section{INTRODUCTION}

The role of incentive compensation is a central and enduring focus of research and practitioner interest in how human resource practices enhance firm performance (Combs, Liu, Hall, \& Kitchen, 2006; Cohen, 2011; Park \& Sturman, 2016; Sung, Choi, \& Kang, 2017). Recently, human resource management scholars have focused on examining executive compensation (Bragaw \& Misangyi, 2017) and the interplay between executive incentives and firm outcomes (Martin, Washburn, Makri, \& Gómez-Mejía, 2015). At the executive level, the design of compensation contracts has been heavily influenced by agency-based reasoning (e.g., Jensen \& Murphy, 1990). However, notwithstanding exhaustive research attention, agency-based models have yet to provide strong evidence of a meaningful relationship between executive pay and firm performance (Seo, 2017). Consequently, the human resource and executive compensation literature offers limited concrete guidance for practitioners seeking to design incentive mechanisms that align the interests of executives with firm stakeholders (Wowak \& Hambrick, 2010).

Classical agency theory suggests that executives respond uniformly to incentives independent of social norms (eg. Jensen \& Meckling, 1976). This view has been implicit in human resource literature exploring the consequences of equity incentives (e.g., Martin, Washburn, Makri, \& Gomez-Mejia, 2015; Pepper, Gore, \& Crossman, 2013). However, this expectation sits uncomfortably with insights from institutional theory (e.g., North, 1990; Scott, 1995) and from human resource management studies on the impact of external contextual factors - and social norms in particular — on the efficacy of compensation and incentives (Merriman \& Sen, 2012; Schlesiger,1983). From an institutional perspective, social norms provide actors with a common understanding of appropriate judgement and conduct (Merriman et al., 2012). As a result of failing to "acknowledge the social context in which principal-agent 
contracts occur” (Wiseman, Cuevas-Rodriguez, \& Gómez-Mejía, 2012: 202), agency-based models are thought to be under-socialized (Aguilera \& Jackson, 2003; Donaldson, 2012; Lubatkin, Lane, Collin, \& Very, 2007). The principal-agent contract can be generalized to any contract between the firm and an employee, in which the employee is empowered to make decisions on behalf of their firm and its shareholders. To the extent that the principal-agent relationship is socially embedded (Granovetter, 1985), social norms represent an important consideration for scholars seeking to enhance agency-based predictions on the motivational impact of equity incentives (Westphal \& Zajac, 2013; Wiseman et al., 2012).

Our aim is to extend human resource research on the motivational consequences of equity-based incentives by casting executives as socially embedded, rather than socially dislocated actors. We focus on local social norms - norms in the area surrounding a firm's headquarters. As senior executives tend to live near their firm's headquarters, the norms and expectations of the local community are thought to influence top management's cognition and behavior (Berrone, Cruz, Gómez-Mejía, \& Larraza-Kintana, 2010; Gómez-Mejía et al., 2007). Hence, notwithstanding globalizing trends, norms of the area surrounding firms' headquarters represent a promising unit of analysis for examining executive behavior and firm outcomes (Marquis \& Battilana, 2009; Thornton, Ocasio, \& Lounsbury, 2012).

Against this backdrop, we explore how a central component of local social norms-local religious norms - influences the motivational effect of CEO equity incentives. At least since Weber (1905), scholars have explored how religious norms affect perceptions and behaviors as well as social and economic development (Chan-Serafin, Brief, \& George, 2013; Iannaccone, 1998; Weaver \& Agle, 2002). Consistent with institutional reasoning (Oliver, 1997; Scott, 1995), individuals living in areas where a large proportion of the population are religious adherents tend 
to conform to religious social norms - even if they are not personally religious (Boone, Khurana, \& Raman, 2013; Stark \& Bainbridge, 1996; van Tubergen, te Grotenhuis, \& Ultee, 2005). Again, consistent with institutional reasoning, extensive empirical studies provide evidence that the strength of local religious social norms shapes the judgment and behavior of executives of locally headquartered firms (Callen \& Fang, 2015; Hilary \& Hui, 2009; McGuire, Omer, \& Sharp, 2012; Shu, Sulaeman, \& Yeung, 2012).

Prior work suggests that the motivational effect of incentives varies with an individual's subjective perceptions and disposition (Cadsby, Song, \& Tapon, 2007; Pappas \& Flaherty, 2006; Wowak \& Hambrick, 2010). As local religious social norms shape managerial judgement and behavior, we advance the argument that local religious social norms influence the effort that CEOs of locally headquartered firms exert in response to equity incentives. Given the unobservable nature of executive effort (Jensen \& Meckling, 1976; Tosi, Werner, Katz, \& Gomez-Mejia, 1997), firm value is a useful proxy for the consequences of executives' effort and actions in response to incentives (Carpenter \& Sanders, 2002; Feldman \& Montgomery, 2015; Sanders \& Hambrick, 2007). Hence, we test our arguments by examining how religious social norms influence the impact of CEO equity incentives on firm value. While we focus on norms as a source of institutional conditioning, we recognize that CEOs' personal religious convictions may also play a role (Chan-Serafin et al., 2013; Weaver \& Agle, 2002). Therefore, in our empirical tests, we address the possibility that CEOs' personal religious convictions, rather than local religious norms, explain our results.

We find strong support for our arguments in a sample of 18,647 firm-years. Our study makes several contributions. First, we advance human resource management research on the performance and motivational consequences of executive incentive mechanisms (cf. Martin et 
al., 2015; Park \& Sturman, 2016; Seo, 2017; Sung et al., 2017). We achieve this by demonstrating the utility of adopting a socially informed approach to exploring the consequences of equity incentives when designing and negotiating compensation contracts. Hence, our work responds to concerns that agency research examining incentive alignment has been undersocialized (e.g., Berrone \& Gómez-Mejía, 2009; Gómez-Mejía et al, Wiseman, \& Johnson, 2005; Westphal \& Zajac, 2013). Second, we advance the human resource and management literature exploring institutional influences—via local religious norms—on executive behavior by infusing insights from the study of executive compensation and individual agency; in doing so, we address concerns that this literature and human resource practice has ignored the role of individual incentives and self-interest (Granovetter, 1985; Park \& Sturman, 2016). Third, we advance human resource research on the relationship between incentives and firm value (e.g., Sung et al., 2017) and the efficacy of pay for performance plans (Gerhart \& Fang, 2014; Gerhart \& Rynes, 2003; Jenkins, Mitra, Gupta, \& Shaw, 1998). By describing the role of social context as an important contingency in the outcomes associated with incentives, we provide an important additional factor that human resource professions should consider when designing these plans and related contracts.

\section{THEORETICAL BACKGROUND}

Human resource scholars and institutional theorists argue that the formal and informal institutional forces prevailing within an actor's environment shape cognition and behavior (Merriman \& Sen, 2012; North, 1990; Schmidtke, 2007; Scott, 2001). These institutional forces include social and cultural norms that generate belief systems and related practices or "logics" (Scott, 2001). Patterns of behavior and prevailing ethical standards can emerge as individuals subconsciously conform to the common perceptions and values in their environment (Marquis, 
Glynn, \& Davis, 2007). The influence of social norms is underpinned by the shared interactions, habits, experience, and language of social networks (Galaskiewicz, 1997; Marquis \& Battilana, 2009). From an institutional theory perspective, recognizing the social embeddedness of actors provides a basis for predicting cognition and behavior (Granovetter, 1985; Merriman \& Sen, 2012).

Reasoning similar to institutional logic has been advanced in the psychology and economics literatures. Social cognition theory (e.g., Tajfel, 1978) describes how actors seek to conform to prevailing norms as a means of supporting self-concept and enjoying a sense of membership of a community. Economic theorists (e.g., Elster, 1989) argue that, due to a sense of membership with a community, actors tend to conform to social norms - even when their actions are unobservable - as breaches of social norms give rise to emotional costs such as feelings of guilt. Hence, even if an actor initially conforms to social norms to avoid sanctions or reap the rewards of social membership, norms become internalized over time, as internal rewards (sense of membership) and sanctions (guilt) supplement external rewards (esteem) and sanctions (shame or ostracization). As a result, norms are also likely to influence behaviors that may not be transparent to others (Cialdini \& Trost, 1998). Of particular relevance, the tendency towards conformity to social norms is thought to be more pronounced in settings where individuals experience greater uncertainty, as is commonly the case in the decisions facing senior executives (Geletkanycz \& Hambrick, 1997).

Drawing on institutional theory and social and cognitive psychology, human resource management scholars - and management scholars more generally - have explored how local social norms and expectations shape executive cognition and decision making. For instance, human resource scholars have demonstrated the role of social norms in incentivizing managers 
toward green investment (Merriman \& Sen, 2012) and in preventing deviant employee behavior (Schmidtke, 2007). Casting executives as socially embedded actors, scholars argue that executives' thoughts and actions are shaped and constrained by social norms (e.g., Geletkanycz \& Hambrick, 1997). As senior executives tend to live near the firm's headquarters, local social norms and expectations are thought to influence executive cognition and behavior (Berrone, Gómez-Mejía, \& Larraza-Kintana, 2010). Local social norms shape executives’ cognitive frame and inform executives' perceptions of what constitutes legitimate behaviour (Gómez-Mejía et al., 2007; Marquis \& Battilana, 2009; Marquis \& Lounsbury, 2007; Schmidtke, 2007). Employees at lower levels also form perceptions of what behaviour is legitimate based on the norms prevailing in a given work location (Schmidtke, 2007). Patterns of behavior can emerge as individuals subconsciously conform to the common perceptions and values in their environment and as individuals consciously adjust their behaviour to enjoy the benefits of social membership (Marquis et al., 2007; Oliver, 1997).

\section{Religious Social Norms}

Dating back to at least Weber's work on how religious social norms shape entrepreneurial behavior and economic development (e.g., Weber, 1905), the influence of religious social norms continues to be a focus of attention in many disciplines of the social sciences (e.g., Guiso, Sapienza, \& Zingales, 2006; Iannaccone, 1998). All major organized religions emphasize the individual's responsibility to others and to society at large. In what is commonly referred to as the Golden Rule, religious adherents are instructed to treat others as they would wish to be treated themselves (Chan-Serafin et al., 2013). Reflecting these common tenets, religious adherents tend to exhibit a lower propensity to engage in criminality and ethically questionable behavior (Kennedy \& Lawton, 1998). All major organized religions also discourage gambling 
and related forms of risk-taking (Ellison \& Nybroten, 1999; Iannaccone, 1998). Extensive studies in economics and psychology demonstrate that religious adherents tend to be more riskaverse (Diaz, 2000; Noussair, Trautmann, van de Kuilen, \& Vellekoop, 2013). The risk aversion associated with religious adherence manifests itself in a wide range of human endeavor, including financial investing (Noussair et al., 2013), entrepreneurialism (Jiang, Jiang, Kim, \& Zhang, 2015) and recreational gambling (Diaz, 2000).

While religious principles impact on the conduct of adherents, as social norms, religious principles also impact on the wider community (van Tubergen et al., 2005). As a social institution, religion can shape cognition and behavior within the community even among members who have not internalized the underlying religious beliefs (Stark \& Bainbridge, 1996). Consistent with institutional arguments on the influence of social norms, individuals living in areas with a large proportion of religious adherents are less likely to engage in ethically questionable conduct and risk-taking, even if they are not personally religious (Boone et al., 2013; Kandori, 1992; Regnerus, 2003; Stark \& Bainbridge, 1996; van Tubergen et al., 2005). For example, Boone (2013) found that the strength of local religious social norms is negatively correlated with the likelihood of residents engaging in aggressive tax avoidance - a practice that is ethically questionable and that exposes the individual to high risk. Similarly, Regnerus (2003) found that juveniles from areas with strong religious social norms are less likely to engage in various forms of delinquency.

We conclude from the above literature review that (1) social norms influence both observable and unobservable behaviors; and (2) that social norms are shaped by local religious beliefs. We will draw upon this literature in our theory that casting CEO cognition and behavior 
as being socially contingent provides a platform for exploring the role of local religious social norms in shaping how CEOs respond to equity incentives.

\section{HYPOTHESES}

\section{Equity-Based Pay and Firm Value}

Human resource literature emphasizes the role of compensation incentives as a mechanism for motivating the CEO to achieve goals that are aligned with those of the firm's shareholders (Martin et al., 2015; Park \& Sturman, 2016; Sung et al., 2017). This literature is grounded in micro-organizational theories of motivation that have stressed relationships between motivation and the rewards on offer (Lawler, 1981; Vroom, 1964) and human resource literature seeking to provide guidance to human resource practitioners when designing compensation contracts. These studies have explored the role of compensation as a means for motivating valueenhancing CEO behaviors and effort (e.g., Cruz, Gómez-Mejia, \& Becerra, 2010; Finkelstein \& Hambrick, 1988; Park \& Sturman, 2016). They have also demonstrated a positive relationship between pay for performance plans and job performance (Gerhart \& Fang, 2014; Gerhart \& Rynes, 2003; Jenkins et al., 1998).

A sub-set of the executive pay for performance compensation that has attracted significant research attention has been equity-based pay: the use of stock and stock options to align the financial interests of principal and agent. Equity-based pay has been argued to create incentives that motivate executives to engage in activities that enhance firm value and activities that destroy firm value (Armstrong, Larcker, Ormazabal, \& Taylor, 2013; Pepper et al., 2013; Sanders \& Hambrick, 2007). To mitigate the value destruction associated with attempts at incentive alignment, scholars have sought to delineate the contradictory incentives in equitybased pay. One approach has focused on examining the incentive effects of stock ownership 
versus the incentive effects of stock options. Stock (or share) ownership is argued to be associated with CEOs directing effort towards value-enhancing activities (e.g., Jensen \& Meckling, 1976; Sanders, 2001). Stock options - the right to buy stock at some point in the future at a specified price — are often argued to be associated with CEOs directing effort towards speculative activities that can be value-destroying (Sanders, 2001; Sanders \& Hambrick, 2007).

A related but distinct approach has been to consider the sensitivity of management's equity wealth to stock price and stock price volatility (e.g., Armstrong et al., 2013; Chava \& Purnanandam, 2010; Coles, Daniel, \& Naveen, 2006). An important advantage of this latter approach is that it focuses on the underlying incentives due to wealth sensitivities-incentives to increase the stock price and incentives to increase stock price volatility - rather than on the type of equity award (stock or stock options) (Martin, Gómez-Mejía, \& Wiseman, 2016).

Consideration of executives' incentives to increase stock price and incentives to increase stock price volatility has proven useful for predicting executive behaviors and firm outcomes (e.g., Chava \& Purnanandam, 2010; Coles et al., 2006). While sensitivity of CEO equity wealth to stock price and sensitivity of CEO equity wealth to stock price volatility are both aspects of equity-based pay -they are thought to have divergent impacts on CEO behavior and firm outcomes (Coles et al., 2006). Therefore, in developing our baseline hypotheses, we address each aspect of equity-based pay in turn, implicitly keeping the other constant.

The sensitivity of CEO equity wealth to stock price reflects the extent to which a CEO shares the gains to wealth from increases in firm value and the downside losses to wealth from decreases in firm value (Nyberg, Fulmer, Gerhart, \& Carpenter, 2010). Hence, the sensitivity of CEO equity wealth to stock price captures the incentives in equity-based pay to direct effort towards value-enhancing activities (Sanders \& Hambrick, 2007)— the largely unobservable 
effort described by classical agency scholars who initially championed equity grants (cf. Jensen \& Meckling, 1976). For example, higher sensitivity of personal wealth to stock price motivates executives to exert effort towards extracting higher returns from existing projects and assets and pursuing value enhancement where it has least impact on firm risk (Chava \& Purnanandam, 2010; Coles et al., 2006). From the above discussion, it follows that the sensitivity of the CEO equity wealth to stock price should positively affect firm value.

Hypothesis 1a: The sensitivity of CEO equity wealth to stock price has a positive impact on firm value.

While the sensitivity of equity wealth to the firm's stock price is a function of both CEOs' stock holdings and stock options, sensitivity of equity wealth to stock price volatility is exclusively a function of stock options. The value of stock options increases with stock price volatility. ${ }^{i}$ Due to the asymmetric payoff from stock options, the sensitivity of personal wealth to stock price volatility incentivizes executives to make decisions that have high potential outcome variance while protecting them from any negative financial consequences of such decisions (Sanders \& Hambrick, 2007). That is, while sensitivity of personal wealth to stock price can align the interests of the CEO and shareholders (per Hypothesis 1a), sensitivity of CEO personal wealth to stock price volatility provides incentives that diverge from shareholder interests. The CEO stands to benefit from making decisions with high outcome variance-due to the positive effect this has on their option wealth (option valuations are positively related to share price variance) - that may disadvantage shareholders by increasing the likelihood of extreme negative outcomes and the discount rate applied to the firm's valuation (Sanders \& Hambrick, 2007). This is because performance volatility (the standard deviation or variance of return on assets or market-based performance) leads to higher weighted average cost of capital used as the discount rate when valuing the firm (Andersen, Denrell, \& Bettis, 2007; Bromiley, Miller, \& Rau, 2001; 
Ruefli, Collins, \& Lacugna, 1999). Therefore, higher CEO wealth sensitivity to stock price volatility reduces the value of the shareholder's investment by incentivizing effort for the CEO to engage in variance increasing activities that are not aimed at increasing share price ('reckless risk taking"). Accordingly, we posit that while sensitivity of CEO equity wealth to stock price has a beneficial effect on firm value (Hypothesis 1a), the sensitivity of CEO equity wealth to stock price volatility has a negative impact on firm value.

Hypothesis $1 \mathrm{~b}$ : The sensitivity of CEO equity wealth to stock price volatility has a negative impact on firm value.

\section{Local Religious Social Norms, Equity-Based Pay, and Firm Value}

We next develop our arguments on how local religious social norms influence CEO behavior in response to equity incentives.

Within classical agency theory, as rational, independent actors, CEOs are assumed to be uniformly motivated by the rewards associated with gains to their personal wealth and to be more responsive to incentives where there is a greater likelihood of effort leading to successful outcomes (Jensen \& Meckling, 1976). Yet, individuals differ in their subjective assessment of the likelihood that their efforts will lead to rewards. Moreover, these differences impact on the motivational power of incentives (Cadsby et al., 2007; Porter \& Lawler, 1968; Wowak \& Hambrick, 2010). For example, Wowak and Hambrick (2010) describe how executives who have higher levels of self-confidence are likely to be more responsive to risk-taking incentives as they have greater confidence that their effort will lead to rewards. While personal traits can influence incentive responsiveness, institutional arguments suggest that social norms also play an important role (Bitektine, 2011). In a similar vein, we posit that by shaping executive cognition and behavior local religious social norms influence CEO responsiveness to the incentives in equity-based pay. 
Given that the CEO is socially embedded, we expect that Hypothesis 1a is contingent upon prevailing local religious social norms. Recall that patterns of behavior emerge as individuals unconsciously conform to the common perceptions and values in their environment (Oliver 1997). In addition, conformity arises from an individual's wish to enjoy the benefits of social membership and avoid the sanction of social exclusion (Kohlberg, 1984; Merriman \& Sen, 2012; Tajfel, 1978). Hence, through both conscious and unconscious mechanisms, religious social norms can shape perceptions and behaviors of individuals who have not internalized the underlying religious belief system (Stark \& Bainbridge, 1996). As senior executives tend to work and their firms headquarters and reside locally their cognition and behaviour is likely to be shaped by local norms (Marquis et al., 2007).

As discussed above, all of the major organized religions instruct their adherents to treat others as they would wish to be treated themselves (the "Golden Rule") (Chan-Serafin et al., 2013) and discourage gambling and related forms of risk-taking (Ellison \& Nybroten, 1999; Iannaccone, 1998). Consistent with institutional reasoning (e.g., Scott, 2001), there is evidence that local religious social norms shape executive decision making in locally headquartered firms in a manner consistent with the patterns of behavior described above. For example, the strength of local religious social norms is associated with a lower likelihood of ethically questionable conduct such as options backdating (Grullon, Kanatas, \& Weston, 2010), financial misreporting (Dyreng et al., 2012), manipulation of the flow of corporate information (Callen \& Fang, 2015), and aggressive tax avoidance (Boone et al., 2013). The strength of local religious social norms is also negatively associated with risk taking by locally headquartered firms. For example, Hilary and Hui (2009) find that executives of firms located in areas with strong religious social norms are less likely to engage in speculative endeavors, as measured by variances of equity returns and 
returns on assets. In a similar vein, Callen and Fang (2015) find that firms located in areas with strong local religious social norms exhibit lower risk of stock price crash. In addition, mutual funds located in areas with strong religious social norms exhibit lower levels of risk taking (i.e., lower fund-return volatility and less "tournament" risk-shifting behavior) (Shu et al., 2012). Further, McGuire et al. (2012) find that local religious social norms are negatively associated with riskier financial reporting practices.

In our baseline hypotheses, we predicted that CEO equity wealth sensitivity to stock price has a positive impact on firm value (Hypothesis 1a) because it incentivizes greater valueenhancing effort, given that the CEO personally benefits from stock price increases.

CEO opportunism regarding the effort to be exerted in pursuit of shareholder interestsshirking - has negative consequences for shareholders. As an agent of the firm's owners, shirking by the CEO equates to inflicting costs on others, which is at odds with the Golden Rule. We suggest that, in a context of stronger social religious norms, the CEO is less likely to behave in a manner that reaps positive utility at the expense of shareholders through sub-optimal effort. Said differently, to the extent that religious social norms discourage shirking, we expect that the incremental impact of incentives on CEO effort will be dampened by religious social norms.

In addition to being dishonest, shirking may result in deteriorating firm performance and thus carries a substantial risk for the CEO - the CEO can be dismissed if viewed by shareholders as not being fully committed in their efforts (Denis \& Denis, 1995; Engel et al., 2003). To the extent that religious social norms discourage risk taking, religious norms are likely to further discourage shirking, and thus further dampen the impact of incentives on CEO effort. That is, the CEO of a firm located in an area with stronger religious norms is less likely to have exerted suboptimal effort in the first instance, meaning that incentives aimed at coaxing greater effort are 
muted. Building on the above discussion, we posit that local religious social norms attenuate the positive relationship between CEO sensitivity to stock price and firm value. Hence:

Hypothesis 2a: The strength of local religious social norms attenuates the positive impact of CEO equity wealth sensitivity to stock price on firm value.

In developing Hypothesis $1 \mathrm{~b}$, we argued that in the context of stock price volatility, CEO wealth enhancement is achieved through higher risk taking which increases the value of CEO options but destroys value for shareholders (Armstrong et al., 2013; Sanders \& Hambrick, 2007). We posit that religious social norms also attenuate CEO responsiveness to the incentives provided by sensitivity of equity wealth to stock price volatility. We form this expectation as religious social norms discourage risk taking and unethical conduct.

Turning first to unethical conduct, recall that while creating greater wealth for the CEO, higher risk taking destroys value for shareholders (Armstrong et al., 2013). As discussed earlier, there is strong evidence that local religious social norms discourage ethically questionable executive behavior (Boone et al., 2013; Callen \& Fang, 2015; Grullon et al., 2010). We reason that strong religious social norms are likely to discourage CEOs from engaging in risk-seeking behavior aimed at enhancing the value of their stock options when it imposes costs on others. Said differently, a CEO located in a community with stronger local religious norms is more likely to deem reckless risk taking to be unethical. Turning next to risk aversion, as previously discussed, religious adherents tend to be more risk averse and religious social norms discourage risk taking (Iannaccone, 1998). Consistent with institutional arguments on the influence of social norms (Marquis et al., 2007), prior studies find that executives of firms headquartered in areas with strong religious social norms tend to be more risk averse (Hilary \& Hui, 2009; Callen \& Fang, 2015; Shu et al., 2012). We reason that in contexts where stronger religious social norms prevail, CEOs are less likely to engage in the risk taking induced by the sensitivity of wealth to 
stock price volatility. In sum, religious social norms regarding ethical conduct and risk aversion are likely to attenuate a CEO's willingness to engage in the activities incentivized by sensitivity of personal wealth to stock price volatility. Hence:

Hypothesis 2b: The strength of local religious social norms attenuates the negative impact of CEO equity wealth sensitivity to stock price volatility on firm value.

\section{Managerial Discretion}

In Hypotheses $2 \mathrm{a}$ and 2b, we described how local religious social norms shape the CEO's response to equity incentives. Next, we extend our arguments by considering how the influence of local religious social norms varies with the latitude of action ("discretion") available to the CEO. Hambrick and Finkelstein (1987) introduced the concept of managerial discretion to explain the circumstances in which executives are likely to have more impact on firm value. In this context, research on managerial discretion provides a bridge between (1) the focus of neoclassical economics on amoral agents who respond to incentives in ways that materially impact firm performance (e.g., Hölmstrom \& Milgrom, 1987), and (2) institutional theorists (e.g., North, 1990; Scott, 2001) who argue that managers are constrained by conventions and norms.

A key insight from the discretion literature is that managers have a more pronounced impact on firm outcomes when they have greater discretion (Finkelstein \& Boyd, 1998;

Hambrick \& Abrahamson, 1995; Hambrick \& Finkelstein, 1987). Building upon this insight, we reason that the influence of local religious social norms is more pronounced in settings where CEOs have greater discretion. That is, we reason that when the CEO has greater discretion, their decisions are likely to be more heavily influenced by local norms, given that they have greater scope for influencing firm policy; thus, religious social norms are likely to have a more pronounced influence on the impact of equity incentives. Consistent with this line of reasoning, 
we posit that the attenuating influence of religious social norms on the positive relationship between CEO equity-wealth sensitivity to stock price and firm value increases with managerial discretion. In a similar vein, we also posit that the attenuating influence of religious social norms on the negative relationship between CEO equity-wealth sensitivity to stock price volatility and firm value increases with managerial discretion.

Hypothesis 3a: Managerial discretion amplifies the attenuating influence of local religious social norms on the positive impact of CEO equity-wealth sensitivity to stock price on firm value.

Hypothesis 3b: Managerial discretion amplifies the attenuating influence of local religious social norms on the negative impact of CEO equity-wealth sensitivity to stock price volatility on firm value.

We summarize our Hypotheses in Figure I.

\section{[INSERT FIGURE I ABOUT HERE]}

\section{METHODS}

\section{Sample}

We obtain our data from several sources. Our initial sample consists of all firms in the Standard and Poor's (S\&P) ExecuComp database for the years 1992-2010. ExecuComp provides annual data on CEO compensation for the firms in the S\&P 1500. The S\&P 1500 combines three leading indices, the S\&P 500, the S\&P MidCap 400, and the S\&P SmallCap 600, which represent the large-cap, mid-sized, and small-cap segments of the U.S. equity market, respectively. Companies included in the S\&P 1500 are considered as a representative universe of publicly listed U.S. firms (S\&P Dow Jones Indices, http://au.spindices.com/). We obtain data on local religious social norms from the Churches and Church Membership files of the Association of Religion Data Archives (ARDA). We obtain firm financial information from the Compustat Fundamental Annual files. We obtain stock price and trading volume information from the 
Center for Research on Security Prices (CRSP) monthly files and analyst coverage information from Institutional Brokers Estimates System (IBES) summary files. To facilitate comparison of the coefficients, all non-binary explanatory variables have been standardized with a mean of zero and standard deviation of one. We used a sample of 18,647 observations for 2,604 U.S. firms.

\section{Measures}

Firm value. As previously discussed, due to the unobservable nature of $\mathrm{CEO}$ effort, firm value is a useful metric in research examining the consequences of incentives. Following prior studies on the performance impact of executive incentives (e.g., Carpenter \& Sanders, 2002; Feldman \& Montgomery 2015), we take Tobin's $Q$ as our measure of firm value. We define Tobin's $Q$ as the ratio of the market value of a firm's assets to its book value. We calculate the market value of assets as the market value of equity plus the book value of assets, minus the book value of equity and deferred taxes — where the market value of equity is the fiscal year-end stock price multiplied by the number of shares outstanding. We winsorize Tobin's $Q$ at both the upper and lower one-percentile to mitigate the effect of outliers observed in the data.

CEO equity incentives. We use ExecuComp, which provides a detailed breakdown on different compensation items for CEOs in companies included in the S\&P 1500 , to calculate measures of $\mathrm{CEO}$ equity incentives. We measure $\mathrm{CEO}$ equity-wealth sensitivity to stock price (Delta) as the natural logarithm of the change in the value of the CEOs stock and option portfolio in response to a one percent increase in the firm's stock price. Conceptually, higher Delta indicates stronger incentives to increase firm's stock price. We measure CEO equity-wealth sensitivity to stock-return volatility (Vega) as the natural logarithm of the change in the value of the CEO's option portfolio in response to a 0.01 unit change in the annualized standard deviation of the firm's stock returns (expressed in decimal terms). Conceptually, higher Vega indicates 
stronger incentives to increase the volatility of the firm's stock returns. As the equity-based compensation typically comprises of both stock and stock option components, Delta is the sum of deltas for these two components (i.e., stock delta and stock option delta). Vega is solely a function of the stock options held by the CEO. For the option component of CEO compensation, Delta and Vega are constructed based on the dividend-adjusted version of the Black and Scholes (1973) option-pricing model following a widely used approach of Core and Guay (2002).

Local religious social norms. We use ARDA data to construct our measures of local religious social norms. ARDA data is collected by the Association of Statisticians of American Religious Bodies and is distributed by the Association of Religion Data Archives. The data is housed in the Social Science Research Institute, the College of Liberal Arts, and the Department of Sociology at the Pennsylvania State University. ARDA contains county-level statistics for 149 religious bodies, including information on the number of adherents to each church (ARDA defines adherents as "all members, including full members, their children, and the estimated number of other regular participants"). ARDA data is published at approximately ten-year intervals: 1971, 1980, 1990, 2000, and 2010. For a detailed discussion of the research methodology, data collection, and sampling procedures see ARDA (2010). ARDA data on the variance in religious adherence between counties has proven to be useful in predicting the conduct of executives of locally headquartered firms (Callen and Fang, 2015; Hilary \& Hui, 2009; McGuire et al., 2012; Shu et al., 2012). As we merge ExecuComp data (which starts in 1992) with ARDA data (which ends in 2010), our sample period is from 1992 to 2010. Thus, we use ARDA data from 1990, 2000, and 2010. Prior research (e.g., Scott, 1987, 1995) suggests that the institutional influence of social norms — including religious norms — tends to be persistent over time. Social norms that emerge from religious belief systems, in particular, are slow to 
change as they are reinforced by rituals and traditions (Guiso et al., 2006; Kieser, 1989). In our sample, the strength of religious social norms changes little between survey periods (between survey correlation is approximately 0.7 ). Therefore, we follow previous studies (e.g., Alesina \& La Ferrara, 2002; Hilary \& Hui, 2009; Shu et al, 2012) by linearly interpolating the data to obtain values for the missing years. However, the (untabulated) results indicate that interpolation has no material impact on our findings.

We calculate the strength of religious social norms (Religious adherence) as the number of religious adherents in the county (as reported by ARDA) divided by the county's population (as provided by the U.S. Census). A higher level of Religious adherence indicates stronger religious social norms (Callen \& Fang, 2015; Hilary \& Hui, 2009). ${ }^{\text {ii }}$ We use the Compustat Company Location Code to match our county information with the location of each firm's headquarters. While Compustat only reports the current state and county of a firm's headquarters, the number of firms that relocate is generally very small (Pirinsky \& Wang, 2006). In a sample of more than 5,000 firms over 15 years, Pirinsky and Wang (2006) find only 118 examples of relocation. In addition, any measurement error in firm location is not likely to be correlated with either CEO equity incentives or our local religious social norms measures, and thus will bias against finding significant results. ${ }^{\text {iii }}$

Managerial discretion. Prior research suggests that managerial discretion is a function of multiple firm characteristics, such as product differentiability, capital intensity, and financial slack (Hambrick \& Finkelstein, 1987; Finkelstein \& Boyd, 1998). In industries that feature higher levels of product differentiation — as opposed to higher levels of commoditizationCEOs are likely to have greater discretion to oversee product development and marketing strategies that contribute to unique features that allow them to offer distinctive value to their 
customers. That is, the CEO is likely to have a wider latitude of action as "means-ends linkages are relatively poorly understood" (Hambrick \& Finkelstein, 1987: 381). Prior studies suggest that boards find it difficult to monitor $\mathrm{CEO}$ — and hence the $\mathrm{CEO}$ has greater discretion — in decisions related to investments in advertising (Rajagopalan \& Prescott,1990) and R\&D (Henderson \& Frederickson, 1996). Following Finkelstein \& Boyd, (1998), we use the average ratio of advertising expenses over sales and the average ratio of $R \& D$ expenses over sales, both estimated using previous five years, to capture product differentiability. In industries that are highly capital intensive, firms tend to find it difficult to change strategy (Ghemawat, 1991) This is because past capital investments, despite being a sunk cost, often create path dependency as the board prefers to find ways to leverage past investments rather than identify new opportunities, which, in turn, limits the CEO's latitude of action (Hambrick \& Finkelstein, 1987). We use the average ratio of property plan and equipment over total assets for the previous five years to capture capital intensity. The more cash resources, the greater capacity the CEO has to take action that is a manifestation of the exercise of discretion (Bromiley, 1991). Said differently, without cash resources, the CEO has less opportunity to exercise their discretionary strategies. We use the average ratio of a firm's cash over total assets for the previous five years to capture financial slack. Using a principal components analysis, we construct a composite measure of managerial discretion (Finkelstein \& Boyd, 1998). The estimated factor has the eigenvalue of 1.79 and explains about 45 percent of common variation of its components. The estimated factor loadings are positive for financial slack and product differentiability, and negative for capital intensity, suggesting that higher values of the composite measure indicate higher levels of managerial discretion (Finkelstein \& Boyd 1998). 
Control variables. We include a variety of firm-level control variables following prior research on the determinants of firm value (Daines, 2001; Fang et al., 2009; Servaes \& Tamayo, 2013). Recall that in developing our hypotheses we have argued that local religious norms influence the (largely unobservable) effort CEOs exert in response to equity incentives. To isolate the influence of religious norms on unobservable effort as opposed to the influence upon observable risk taking, we control for variables that may be positively associated with strategic risk taking (Sanders, 2001). These include Capital expenditure, $R \& D$, and Leverage. Capital expenditure is the ratio of the sum of fixed capital expenditure and acquisition over the book value of assets. $R \& D$ is the ratio of $\mathrm{R} \& \mathrm{D}$ expenses over the book value of assets. Leverage is the ratio of the long-term debt over the book value of assets. Capital expenditure, R\&D and long term debt are perceived as risky by executives (Larraza-Kintana et al., 2007) and are commonly used to operationalize strategic risk taking given each rely on uncertain future performance to ensure adequate returns and avoid bankruptcy (Devers et al., 2008; Martin et al., 2013).

To control for the "momentum" effect in stock returns (Jegadeesh \& Titman, 1993) that could influence both CEO equity incentives and firm value, we include Past stock returns, which is a firm's cumulative stock returns over the fiscal year. We also include Firm size and Firm age to account for the size of the firm as well as its lifecycle. Firm size is the natural logarithm of the book value of assets. Firm age is the natural logarithm of a firm's age, defined as the number of years of financial data available in the Compustat database prior to a firm's fiscal year-end. We also include Advertising to control for customer awareness of the firm. Advertising is the ratio of advertising expenses over the book value of assets. Further, we include Return volatility, computed as the standard deviation of monthly firm-specific stock returns over the past three years prior to a firm's fiscal year-end, to control for a firm's stock market risk. We estimate firm- 
specific returns as the regression residuals of firm's monthly stock returns on the Fama and French (1993) risk factors. We also include Analyst coverage to control for a firm's information environment. Analyst coverage is the natural logarithm of one plus the number of analysts covering the stock over the fiscal year.

While all major organized religions advocate the Golden Rule, religious social norms may differ depending on the religious composition of the community. In controlling for this possibility, we consider the ratio of Catholics to Protestants-given that these two groups account 87 percent of religious adherents in the U.S. (ARDA 2010). While we have no expectation that Catholics and Protestants vary systematically in their religious beliefs or ethical standards, prior studies suggest that Catholic and Protestant social norms differ in their tolerance towards risk taking (Diaz, 2000; Ellison \& Nybroten, 1999; Hoffman, 2000; Ozment, 1991). Moreover, these differences can potentially impact on risk preferences of executives of locally headquartered firms (e.g., Hilary \& Hui, 2009; El Ghoul et al., 2012; Kumar, Page, \& Spalt, 2011; Shu et al., 2012). For this reason, in testing our hypotheses, we control for the religious composition of the community. In our setting, the dominant religious institutions are ChristianCatholics and Protestants account for 87 percent of religious adherents in the U.S. (ARDA 2010). Therefore, following prior studies (e.g., Kuma et al., 2011; Shu et al., 2012), we controlled for the impact of religious composition by including the ratio of Catholics to Protestants. We calculate Religious composition as the ratio of the Catholics to Protestants in the county where each firm's headquarters is located (Kumar et al., 2011; Shu et al., 2012).

It is also possible that local social norms, other than religious norms, could influence a CEO's response to equity incentives. To that end, we include the political orientation of each county (Political orientation), measured as the number of votes received by the Democratic 
candidate divided by the number of votes received by the Republican candidate in Presidential elections. We control for level of higher education in each county (Education), calculated as the proportion of the population over the age of 25 with a bachelor's degree or higher. Finally, we control for ethnic characteristics (Minority), calculated as the proportion of racial minorities. The data required for construction of these variables were obtained from U.S. Census Bureau. Similar to Religious adherence, we linearly interpolate these variables between election years for our Political orientation measure and U.S. census years for Education and Minority measures.

\section{RESULTS}

We report the descriptive statistics for our sample in Table I. The mean Tobin's $Q$ for our sample firms is 1.84 , the mean Delta is 5.33 , and the mean Vega is 3.98. A typical firm in our sample is located in a county with Religious adherence of $0.54 .{ }^{\text {iv }}$ In Figure II we provide a graphical representation of Religious adherence, which indicates a substantial variation in the strength of local religious norms between counties. Untabulated results indicate that the highest variance inflation factor (VIF) among the explanatory variables is 2.37 , which is well below the common threshold of five (O'Brien, 2007). Based on these results, we conclude that multicollinearity does not pose a concern in our analysis.

\section{[INSERT TABLES I AND II AND FIGURE II ABOUT HERE]}

We conduct two tests of Hypotheses 1a and 1b. In the first test, we regress Tobin's $Q$ on Delta, Vega, and a set of firm-level control variables described above. To address potential endogeneity concerns, we estimate our model using an instrumental variable approach. We use industry-level Delta and Vega based on three-digit Standard Industry Classification (SIC) codes as instruments (Kale et al., 2009). The model is estimated with both firm- and year-fixed effects included, based on the (untabulated) results of the Hausman (1978) test, which strongly rejects 
random effects specification in our sample. By including firm-fixed effects, we explicitly control for heterogeneity among firms induced by some observable (or unobservable) persistent characteristic (e.g., Fang, Noe, \& Tice, 2009; Servaes and Tamayo 2013). In particular, inclusion of firm-fixed effects controls for factors such as firm's industry affiliation and geographic location of firm's headquarters. In the second test, we exploit the stock option expensing regulation of year 2004 as an exogenous shock to Delta and Vega (Chava \& Purnanandam, 2010). We regress changes in Tobin's $Q$ around the year when regulation became effective on changes in Delta and Vega, and changes in control variables over the same period. The results in Table II show that Tobin's $Q$ is positively related to Delta $(p<0.01)$ and is negatively related to Vega $(p<0.01)$, supporting our baseline hypotheses.

Next, we test Hypotheses 2a and 2b, which predict that the strength of local religious social norms attenuates the impact of $\mathrm{CEO}$ equity incentives on firm value. To examine the influence of local religious social norms on the equity incentives-firm value relationship, we use a set of nested models. Model 1 includes firm-level control variables only. Model 2 includes Delta, Vega, and firm-level controls. In Model 3, we add county-level controls (both separately and interacted with Delta and Vega), and Religious adherence. Model 4 is our fully specified model, which includes the moderating effects of Religious adherence on the CEO equity incentives-firm value relationship. For brevity, we leave the effects of county-level controls in Models 3 and 4 untabulated. All models are estimated with firm-and year-fixed effects included. ${ }^{\mathrm{v}}$ We report the results in Table III. The corresponding standard errors adjusted for heteroskedasticity and clustering by firm are in parentheses. The coefficient for the interaction term Delta $\times$ Religious adherence is negative and significant $(b=-0.09, p<0.01$, see also Figure III), providing support for Hypothesis 2a. The coefficient for the interaction term Vega $\times$ 
Religious adherence is positive and significant ( $b=0.04, p=0.03$, see also Figure IV), providing support for Hypothesis $2 \mathrm{~b}$. Change in $\mathrm{R}^{2}$ of the model resulting from adding these two interaction terms is statistically significant $(F$-statistic $=37.04, p<0.01)$.

The influence of Religious adherence on the strength of the CEO equity incentives-firm value relationship is economically meaningful. Results in Table III (Model 4) suggest that the coefficient for Delta is 0.46 and the coefficient for Vega is -0.09 when Religious adherence and county-level moderating control variables (untabulated for brevity) are at their sample means. Thus, a one standard deviation increase in Religious adherence results, on average, in a decrease of 19.5 percent in the positive effect of Delta on firm value. Further, a one standard deviation increase in Religious adherence, on average, mitigates the negative effect of Vega on firm value by 44.4 percent.

[INSERT TABLE III, FIGURES III AND IV ABOUT HERE]

Next, we test Hypotheses $3 \mathrm{a}$ and $3 \mathrm{~b}$, which predict that the attenuating influence of Religious adherence on the strength of the CEO equity incentives-firm value relationship increases with managerial discretion. To test these hypotheses, we estimate our baseline model twice: once for the high managerial discretion sub-sample (i.e., firm-year observations with the values of Managerial discretion above its sample median) and once for the low managerial discretion sub-sample (firm-year observations with the values of Managerial discretion below its sample median). We report the results in Table IV. For the high managerial discretion subsample, the coefficient for the interaction term Delta $\times$ Religious adherence is negative and significant $(b=-0.12, p<0.01)$, and the coefficient for the interaction term Vega $\times$ Religious adherence is positive and marginally significant $(b=0.05, p=0.07$, one-tail). For the low managerial discretion sub-sample, the coefficient for the interaction term Delta $\times$ Religious 
adherence is marginally significant ( $b=-0.03, p=0.07$, one-tail), and the coefficient for the interaction term Vega $\times$ Religious adherence is not significant $(b=0.01, p=0.62)$. The difference between the coefficients across the two sub-samples is negative and significant for the Delta $\times$ Religious adherence interaction term $(p<0.04)$ and is positive but not significant for the Vega $\times$ Religious adherence interaction term $(p=0.25)$. Collectively, these results are generally consistent with the notion that the attenuating influence of Religious adherence on the strength of the CEO equity incentives-firm value relationship increases with managerial discretion, and thus provide some support for Hypotheses $3 \mathrm{a}$ and $3 \mathrm{~b}$.

\section{[INSERT TABLE IV ABOUT HERE]}

To assess the robustness of our findings, we conducted a variety of tests (untabulated for brevity). Research on the relationship between prevailing norms and firm outcomes (i.e., Crossland \& Hambrick, 2007; Fauchart \& von Hippel, 2008) is challenged by the endogenous nature of CEOs' personal values and beliefs. While we focus on the influence of religious social norms, CEOs' personal religious convictions ("religiosity") may also play a role (Chan-Serafin et al., 2013; Weaver \& Agle, 2002). Therefore, we conducted two tests to address endogeneity concerns that arise if CEOs with strong religious convictions move to an area where their beliefs are shared by a large proportion of the population.

In the first test, we re-estimated our baseline model with CEO-fixed effects included. By including CEO-fixed effects, we controlled for unobservable persistent personal traits of CEOs (such as religiosity). If our results are attributed to CEOs with strong religious convictions move to an area where their beliefs are shared by a large proportion of the population, personal religiosity — rather than, or in addition to, religious social norms - may explain our results. If our results are attributable to CEO religiosity, the documented effects of local religious norms on the 
CEO incentives-firm value relationship should become insignificant when CEO-fixed effects are included. In the second test, we re-estimated our baseline model using an instrumental variable approach. We used four county-level demographic characteristics as instruments: (i) median age in the county, (ii) female-to-male ratio in the county, (iii) proportion of married couples in the county, and (iv) natural log of median income in the county (Iannaccone, 1998). ${ }^{\mathrm{vi}}$ For both tests, our results remain qualitatively unchanged, suggesting that our findings are unlikely to be driven by CEO religiosity.

We also considered the possibility that the effects of Religious adherence on equity incentives-firm value relationship could be driven by industry clusters in certain geographic locations (e.g., technology firms in California versus financial services firms in New York and Boston), in which case our findings could reflect differential responsiveness of CEOs to equity incentives across different industries. We note that, as we estimate our model with firm-fixed effects (which capture, among other firm-level factors, the effects of firm's industry affiliation), such possibility is remote. Nonetheless, to further dispel this concern, we modified our baseline model to include interaction terms between CEO equity incentives (i.e., Delta and Vega) and firms' major industry type dummy variables. The results indicate that inclusion of these additional controls has no material impact on our findings.

We also considered potential endogeneity arising from social norms influencing the structure of CEO incentives. To examine this issue, we re-estimated our baseline model using Delta and Vega orthogonalized with respect to local religious norms. Our results remain qualitatively unchanged.

For most of the firms' in our sample, their operations are spread across multiple counties (and for some, across different countries). Therefore, in our setting, local religious norms in the 
county where a firm's headquarters are located are unlikely to be correlated with a firm's business opportunities. Nonetheless, for completeness, we conducted additional analyses to further examine this issue. Specifically, we modified our model to include the following additional local controls (both interacted with Delta and Vega and separately): (i) business attractiveness rank, (ii) labor supply rank, (iii) quality of life rank, (iv) percentage of urban population, (v) alcohol consumption rate, and (vi) percentage of population that is incarcerated. We obtained data for these variables from the Bureau of Justice Statistics, the National Institute on Alcohol Abuse and Alcoholism and Forbes magazine. Inclusion of these controls had no material impact on our findings.

We also considered the possibility that our findings are influenced by geographic factors. Specifically, that spatial correlation effects bias our estimated coefficients and/or standard errors (Doh \& Hahn, 2008). To address this issue, we modified our model to include the following set of additional controls: mean Tobin's $Q$, mean Delta, and mean Vega for the firms headquartered in the same county. Referred to as "spatial lag model," such model is consistent with the equilibrium outcome of a spatial or social interaction process, in which the value of the dependent variable for one agent is jointly determined with that of the neighboring agents (Anselin, 2006). Including these variables did not change the pattern or significance of our results, suggesting that our findings are robust to potential spatial correlation effects.

We also considered alternative measures of Religious composition. Research on the influence of religious social norms typically groups Mainline and Evangelical Protestants together (e.g., Hilary \& Hui, 2009; Shu et al., 2012). However, El Ghoul et al. (2012) suggest that it may be better to consider these groups separately. To examine this issue, we examined two alternative measures of Religious composition: the ratio of Catholics to Mainline Protestants and 
the ratio of Catholics to Evangelical Protestants. We estimated our baseline model three times: once using the ratio of Catholics to Evangelical Protestants, once using the ratio of Catholics to Mainline Protestants, and once when both measures are included. The effects of religious adherence on the CEO equity incentives-firm value relationship retain their predicted signs and statistical significance in all three model specifications. The magnitude of the effect of Religious composition on the CEO equity incentives-firm value relationship appears to be slightly larger for the Catholics to Evangelical Protestants ratio.

\section{DISCUSSION}

The aim of this study was to explore how social norms influence the motivational effect of CEO equity incentives, as evidenced by the relationship between the incentives in CEO equity-based pay and firm value. Our approach was to focus on the influence of religious social norms in the area surrounding firms' headquarters. Our findings supported the baseline predictions that the sensitivity of CEO equity wealth to stock price was positively related to firm value and that sensitivity of CEO equity wealth to stock volatility was negatively related to firm value. More importantly, we found that the strength of local religious social norms (captured at the county level by the proportion of religious adherents in the population) attenuated the relationship between equity incentives and firm value. Further, we found the impact of local religious social norms increased with the level of managerial discretion. These findings have numerous implications for human resource practice and theory related to the study of incentives and firm performance that we elaborate upon below.

\section{Implications for Human Resource Practitioners}

Our analyses address an issue of central importance for human resource practitionersthe implications of incentives for firm performance (Combs et al., 2006; Cohen, 2011; Sung et 
al., 2017). Given the pervasive use of equity based incentives in an attempt to enhance firm performance, our findings with regard to the contingencies in this relationship have important implications. For boards and compensation consultants, equity ownership and stock options dominate the discussion on executive incentives. Our findings provide human resource professionals, boards and compensation committees with a new lens for considering the likely impact of equity based incentives; specifically, it prompts us to consider the financial characteristics of an executive's stock portfolio (sensitivity of equity wealth to stock price and sensitivity of equity wealth to stock price volatility) and the local social norms - such as strength of local religious norms - when designing compensation contracts for senior management.

Second and building on our first point, for human resource practitioners seeking to create incentives compatible with firm goals, our findings demonstrate the importance of considering the social context within which incentive mechanisms operate. Prior human resource literature has demonstrated that in general, pay for performance schemes have positive outcomes for performance (Gerhart \& Fang, 2014; Gerhart \& Rynes, 2003; Jenkins et al., 1998). Equity based pay equates to pay for performance in that equity is often part of executive compensation contracts, is often granted due to higher performance and the value of these grants is positively correlated with future performance. We add a qualification for practitioners to consider when designing pay for performance plans. Our findings suggest that it is necessary to be explicit in considering the social context that the executive is operating within. Hence, human resource professionals ought to take social norms into consideration when determining the likely impactpositive and negative — of equity based pay. An encouraging finding from our study — in the context of agency concerns arising from incentive design - is that the negative impact of dysfunctional incentives is curtailed in settings where social norms discourage risk taking and 
unethical conduct. However, such settings are also likely to limit the impact of equity incentives in enhancing firm performance.

Finally, our findings demonstrate that, when embracing the social context within which incentive mechanisms and pay for performance plans operate, attention should be given to the level of discretion available to executives. Our analyses indicate that when executives have greater discretion, prevailing social norms have a more pronounced influence on incentive responsiveness. As discretion tends to become more pronounced with seniority, the question of social context should be given particular attention when designing incentive mechanisms for senior executives.

\section{Implications for Incentives and Agency Theory}

First, our work demonstrates that social context is an important contingency in the design of executive incentive schemes. As Westphal and Zajac (2013: 624) note, "for agency theory, the only relevant role in understanding a corporate leader's way of thinking and acting is that she/he is an agent." Whereas agency theory has been criticized for under-socializing principal-agent relationships, research adopting an institutional perspective has been criticized for being oversocialized - that is, placing too much emphasis on the socially embedded nature of individual conduct and ignoring the role of personal incentives (Granovetter, 1985). Our work bridges the gap between classical agency theory, focused on rational independent actors, and institutional theory focused on socially constituted actors.

We complement prior theoretical (Wowak \& Hambrick, 2010) and experimental (Cadsby et al., 2007) studies pointing to the heterogeneity in executive responses to incentives. We extend this research stream by exploring the role of social norms as a source of heterogeneity. In addition, we provide greater theoretical specificity with respect to the influence of social norms 
on the motivational effect of incentives. Integrating arguments from agency theory and institutional theory, we develop a conceptual framework that describes how social norms affect incentive responsiveness. Further, we describe how the influence of social norms on incentive responsiveness becomes more pronounced as the level of discretion increases. While we focus on CEOs, our work provides a framework for considering the impact of social norms on incentive responsiveness further down the organization, and for research examining the influence of norms other than religious social norms. We hope that our findings encourage further research on how local social norms influence the consequences of incentives for employees other than the CEO and for the consequences of human resource management practices more broadly.

Second, our findings add to management research examining informal institutional influences on executive behavior (e.g., Galaskiewicz, 1997; Marquis \& Lounsbury, 2007). To date, this stream of research has focused primarily on the norms that prevail within professions and among elite groups. For example, prior studies have explored the influence of city-level corporate norms and local elite norms (Galaskiewicz, 1997; Marquis et al., 2007; Lounsbury, 2007). In contrast, the influence of the local community surrounding firms' headquarters has been largely overlooked in the management literature (Marquis \& Battilana, 2009). Yet, as Berrone et al. (2010) argue, given that executives tend to live near their corporate headquarters, the values and expectations of the local community can also shape executive cognition and behavior. Consistent with this line of reasoning, we describe how a consideration of local social norms can inform research on CEO compensation and the consequences of incentives.

Third, we advance human resource research on the relationship between employee incentives and firm value. Extensive agency-based studies argue for the merits of linking managerial and employee compensation to firm performance as a means of achieving incentive 
alignment (Jensen \& Meckling, 1976). Yet, empirical support for the expectation that compensation contracts impact on firm value has been equivocal at best (Tosi et al., 2000;

Devers et al., 2008). In response, management scholars have sought to explore contingencies that affect the efficacy of compensation contracts, such as top management team pay dispersion (Carpenter \& Sanders, 2002) and managerial discretion (Finkelstein \& Boyd, 1998). We highlight the role of a further contingency in the incentives-performance relationship. By describing how local religious social norms influence the relationship between CEO equity incentives and firm value, our findings suggest that the practice of overlooking prevailing social norms may go some way towards explaining the mixed results in prior studies.

\section{Limitations and Future Research}

Similar to prior studies (e.g., Hilary \& Hui, 2009; Shu et al., 2012), we draw on ARDA data to capture the strength of local religious social norms. An alternative approach would be to undertake a laboratory experiment with CEOs where religious social norms are primed. In designing our study, we considered this alternative approach. However, it presents several major challenges. First, senior executives are extremely reluctant to submit themselves to psychological tests / participate in laboratory experiments. Second, a CEO's decision to participate or not to participate in an experiment could, in part, be driven by values induced by local norms and/or by a CEO's mood induced by firm's performance (e.g., Hayward \& Hambrick, 1997), in which case results would be contaminated by self-selection bias. Third, a laboratory experiment would limit our analysis to a specific point in time, and thus not allow us to exploit time variations in firm value and CEO's equity incentives (i.e., delta and vega), thereby substantially limiting the econometric power of our tests. A second approach would be to survey CEOs about the influence of religious social norms. However, reliance on survey data would be fraught with problems 
arising from reactivity and social desirability (Gupta et al., 2017). In particular, we would have to rely on respondents' abilities to accurately gauge the extent to which norms consciously and subconsciously shape their cognition and behavior. In light of such challenges, Webb et al. (1966) advocated the use of unobtrusive measures. Following Webb et al.'s (1966) recommendation, the use of unobtrusive measures to capture executive cognition is a common practice in management literature (Cycyota \& Harrison, 2006; Hambrick \& Mason, 1984). Nonetheless, we see future experimental work as a natural and welcome complement to the current study.

Management scholars seeking to examine how social norms and cultural values influence cognition, behavior, and firm outcomes commonly focus on one social or cultural norm (e.g. Chua et al., 2015; Fauchart \& von Hippel, 2008; Montiel et al., 2012) as it enables the building of strong theoretical arguments associated with the norm (or value). Following this approach, we focus solely on the influence of religious social norms while including other social norms as controls in our empirical analyses. Institutional reasoning suggests that other social norms may also influence incentive responsiveness. Future studies could usefully explore how prevailing norms beyond those associated with religious adherence influence incentive responsiveness. Our theory that local religious norms shape executive behavior is not incompatible with the idea that individual religious convictions also shape behavior (Weaver \& Agle, 2002). While we find that local religious norms have an incremental behavioral impact, after controlling for executive's individual religious convictions (through using executive fixed effects), the interplay between local norms and individual convictions in shaping executive behavior provides opportunities for future research. Also, as the first study to explore the impact of religious social norms on incentive responsiveness, we focus on the overall level of religious adherence. Future studies 
exploring how differing religious traditions influence incentive responsiveness would be welcome. For instance, in the context of US, where Christians account for the vast majority of religious adherents, it would be interesting to explore the impact of various Christian traditions. 


\section{REFERENCES}

Aggarwal, R. K. \& Samwick, A. A. (2003). Why do managers diversify their firms? Agency reconsidered. Journal of Finance, 58:1, 71-118.

Alesina, A. \& La Ferrara, E. 2002. Who trusts others? Journal of Public Economics, 85(2), 20734.

Andersen, T. J., Denrell, J. \& Bettis, R. A. (2007). Strategic responsiveness and Bowman's riskreturn paradox. Strategic Management Journal, 28(4), 407-29.

Archives, A. o. R. D. 2010. Churches and church membership in the United States, 2010. Collected by the Association of Statisticians of American Religious Bodies (ASARB) and distributed by the Association of Religion Data Archives.

Armstrong, C. S., Larcker, D. F., Ormazabal, G. \& Taylor, D. J. (2013). The relation between equity incentives and misreporting: the role of risk-taking incentives. Journal of Financial Economics, 109(2), 327-50.

Berrone, P., Cruz, C., Gómez-Mejía, L. R. \& Larraza-Kintana, M. (2010). Socioemotional wealth and corporate responses to institutional pressures: do family-controlled firms pollute less? Administrative Science Quarterly, 55(1), 82-113.

Berrone, P. \& Gómez-Mejía, L. R. (2009). Environmental performance and executive compensation: An integrated agency-institutional perspective. Academy of Management Journal, 52(1), 103-26.

Bitektine, A. (2011). Toward a theory of social judgments of organizations: The case of legitimacy, reputation, and status. Academy of Management Review, 36(1), 151-179.

Black, F. \& Scholes, M. (1973). The pricing of options and corporate liabilities. Journal of Political Economy, 81(3), 637-54.

Boone, J. P., Khurana, I. K. \& Raman, K. K. (2013). Religiosity and tax avoidance. Journal of the American Taxation Association, 35(1), 53-84.

Bragaw, N. A. \& Misangyi, V. F. (2017) The value of CEO mobility: contextual factors that shape the impact of prior CEO experience on market performance and CEO compensation. Human Resource Management, 56(2), 243-265.

Bromiley, P. (1991). Testing a causal model of corporate risk taking and performance. Academy of Management Journal, 34(1), 37-59.

Bromiley, P., Miller, K. D. \& Rau, D. (2001). Risk in strategic management research. In The Blackwell Handbook of Strategic Management, (pp 259-88) Blackwell. Malden, MA..

Cadsby, C. B., Song, F. \& Tapon, F. (2007). Sorting and incentive effects of pay for performance: an experimental investigation. Academy of Management Journal, 50(2), 387-405.

Callen, J. L. \& Fang, X. (2015). Religion and stock price crash risk. Journal of Financial and Quantitative Analysis, 50(1-2), 169-95.

Carpenter, M. \& Sanders, G. (2002). Top management team compensation: the missing link between CEO pay and firm performance? Strategic Management Journal, 23(4), 367-75.

Chan-Serafin, S., Brief, A. P. \& George, J. M. (2013). How does religion matter and why? Religion and organizational sciences. Organization Science, 24(5), 1585-600.

Chava, S. \& Purnanandam, A. (2010). CEOs versus CFOs: incentives and corporate policies. Journal of Financial Economics, 97(2), 263-278.

Chua, R. Y., Roth, Y., and Lemoine, J.-F. (2015). The impact of culture on creativity: How cultural tightness and cultural distance affect global innovation in crowdsourcing work, Administrative Science Quarterly, 60(2), 189-227.

This article is protected by copyright. All rights reserved. 
Cialdini, R. B., \& Trost, M. R. (1998). Social influence: Social norms, conformity, and compliance. In D. T. Gilbert, S. T. Fiske, \& G. Lindzey (Eds.), The handbook of social psychology (Vol 2, pp. 151-192). Boston: McGraw-Hill.

Cohen, D. J. (2011). Celebrating 50 years: The more things change, the more they remain the same. Human Resource Management, 50(5), 571-74.

Coles, J. L., Daniel, N. D. \& Naveen, L. (2006). Managerial incentives and risk-taking. Journal of Financial Economics, 79(2), 431-68.

Combs, J., Liu, Y., Hall, A. \& Ketchen, D. (2006). How much do high-performance work practices matter? A meta-analysis of their effects on organizational performance. Personnel Psychology, 59(3), 501-28.

Core, J. E. \& Guay, W. R. (2002). Estimating the value of stock option portfolios and their sensitivities to price volatility. Journal of Accounting Research, 40:3, 613-30.

Crossland, C. \& Hambrick, D. C. (2007). How national systems differ in their constraints on corporate executives: A study of CEO effects in three countries. Strategic Management Journal, 28(8), 767-89.

Cruz, C. C., Gómez-Mejia, L. R. \& Becerra, M. (2010). Perceptions of benevolence and the design of agency contracts: CEO-TMT relationships in family firms. Academy of Management Journal, 53(1), 69-89.

Cycyota, C. S. \& Harrison, D. A. (2006). What (not) to expect when surveying executives a meta-analysis of top manager response rates and techniques over time. Organizational Research Methods, 9(2), 133-160.

Daines, R. (2001). Does Delaware law improve firm value? Journal of Financial Economics, 62(3), 525-58.

Denis, D.J., \& Denis, D. K. (1995). Performance changes following management dismissals. Journal of Finance, 50(4), 1029-1057.

Devers, C. E., McNamara, G., Wiseman, R. M. \& Arrfelt, M. (2008). Moving closer to the action: examining compensation design effects on firm risk. Organization Science, 19(4), 548-66.

Di Stefano, F., King, A. \& Verona, G. (2014). Kitchen confidential? Norms for the use of transferred knowledge in gourmet cuisine. Strategic Management Journal, 35(11), 164570.

Diaz, J. D. (2000). Religion and gambling in sin-city: a statistical analysis of the relationship between religion and gambling patterns in Las Vegas residents. Social Science Journal, $37(3), 453-58$.

Donaldson, T. (2012). The epistemic fault line in corporate governance. Academy of Management Review, 37(2), 256-71.

Dyreng, S. D., Hanlon, M. \& Maydew, E. (2012). Where do firms manage earnings. Review of Accounting Studies, 17(3), 649-87.

El Ghoul, S., Guedhami, O., Ni, Y., Pittman, J. \& Saadi, S. (2012). Does religion matter to equity pricing? Journal of Business Ethics, 111(4), 491-518.

Ellison, C. G. \& Nybroten, K. A. (1999). Conservative Protestantism and opposition to statesponsored lotteries: Evidence from the 1997 Texas poll. Social Science Quarterly, 40(2), 356-69.

Elster, J. (1989). Social norms and economic theory. Journal of Economic Perspectives, 3(4): 99117. 
Engel, E., Hayes, E. M., \& Wang, X. (2003). CEO turnover and properties of accounting information. Journal of Accounting and Economics, 36(1-3), 197-226.

Fama, E. F. \& French, K. R. (1993). Common risk factors in the returns on stocks and bonds. Journal of Financial Economics, 33(1), 3-56.

Fang, V. W., Noe, T. H. \& Tice, S. (2009). Stock market liquidity and firm value. Journal of Financial Economics, 94(1), 150-69.

Fauchart, E. \& von Hippel, E. (2008). Norms-based intellectual property systems: the case of french chefs. Organization Science, 19(2), 187-201.

Feldman, E. R. \& Montgomery, C. A. (2015). Are incentives without expertise sufficient? Evidence from fortune 500 firms. Strategic Management Journal, 36(1), 113-22.

Finkelstein, S. \& Boyd, B. K. (1998). How much does the CEO matter? The role of managerial discretion in the setting of CEO compensation. Academy of Management Journal, 41(2), 179-99.

Finkelstein, S. \& Hambrick, D. C. (1988). Chief executive compensation: A synthesis and reconciliation. Strategic Management Journal, 9(6), 543-58.

Galaskiewicz, J. (1997). An urban grants economy revisited: Corporate charitable contributions in the twin cities, 1979-81, 1987-89. Administrative Science Quarterly, 42(3), 445-71.

Gans, J., Hsu, D. \& Stern, S. (2002). When does start-up innovation spur the gale of creative destruction? RAND Journal of Economics, 33(4), 571-86.

Geletkanycz, M. A., \& Hambrick, D. C. (1997). The external ties of top executives: Implications for strategic choice and performance. Administrative Science Quarterly, 42, 654-681.

Gerhart, B., \& Fang, M. (2014). Pay for (individual) performance: issues, claims, evidence and the role of sorting effects. Human Resource Management Review, 24(1), 41-52.

Gerhart, B., \& Rynes, S.L. (2003). Compensation: theory, evidence, and strategic implications. Evaluating form and function of PFP plans. Thousand oaks, CA: Sage.

Ghemawat, P. (1991). Commitment: The dynamic of strategy. New York: Free Press.

Gómez-Mejía, L. R., Haynes, K. T., Núñez-Nickel, M., Jacobson, K. J. \& Moyano-Fuentes, J. (2007). Socioemotional wealth and business risks in family-controlled firms: Evidence from Spanish olive oil mills. Administrative Science Quarterly, 52(1), 106-37.

Gómez-Mejía, L. R., Wiseman, R. M. \& Johnson, B. (2005). Agency problems in diverse contexts: A global perspective. Journal of Management Studies, 42(7), 1507-20.

Granovetter, M. 1985. Economic action and social structure: The problem of embeddedness. American Journal of Sociology, 91(3), 481-510.

Grullon, G., Kanatas, G. \& Weston, J. (2010). Religion and corporate (mis)behavior. Working paper, Rice University.

Guiso, L., Sapienza, P. \& Zingales, L. (2006). Does culture affect economic outcomes? Journal of Economic Perspectives, 20, 23-48.

Gupta, A., Briscoe, F., \& Hambrick, D. C. (2017). Red, blue, and purple firms: Organizational political ideology and corporate social responsibility. Strategic Management Journal, 38(5), 1018-1040.

Halek, M. \& Eisenhauer, J. (2001). Demography of risk aversion. The Journal of Risk and Insurance, 68(1), 1-24.

Hambrick, D. C. \& Abrahamson, E. (1995). Assessing managerial discretion across industries: A multimethod approach. Academy of Management Journal, 38(5), 1427-41.

Hambrick, D. C. \& Finkelstein, S. (1987). Managerial discretion: A bridge between polar views of organizational outcomes. Research in Organizational Behavior, 9, 369-406. 
Hambrick, D. C. \& Mason, P. A. (1984). Upper echelons: The organization as a reflection of its top managers. Academy of Management Review, 9(2), 193-206.

Hausman, J. A. (1978). Specification tests in econometrics. Econometrica, 46(6), 1251-71.

Hayward, M. L. \& Hambrick, D. C. (1997). Explaining the premiums paid for large acquisitions: Evidence of CEO hubris. Administrative Science Quarterly, 42(1). 103-127.

Henderson, A. D. \& Fredrickson, J. W. (1996). Information-processing demands as a determinant of CEO compensation. Academy of Management journal, 39(3), 575-606.

Hilary, G. \& Hui, K. (2009). Does religion matter in corporate decision making in America? Journal of Financial Economics, 93(3), 455-73.

Hoffman, J. P. (2000). Religion and problem gambling in the U.S. Review of Religious Research, 41(4), 488-509.

Hölmstrom, B. (1979). Moral hazard and observability. Bell Journal of Economics, 10(1), 74-91.

Iannaccone, L. (1998). Introduction to the economics of religion. Journal of Economic Literature, 36(3), 1465-96.

Jensen, M. C. \& Meckling, W. H. (1976). Theory of the firm: Managerial behavior, agency costs and ownership structure. Journal of Financial Economics, 3(4), 305-60.

Jenkins, G.D., Mitra A., Gupta N., \& Shaw J.D. (1998). Are financial incentives related to performance? A meta-analytic review of empirical research. Journal of Applied Psychology, 83(5), 777-787.

Jiang, F., Jiang, Z., Kim, K. A. \& Zhang, M. (2015). Family-firm risk-taking: does religion matter? Journal of Corporate Finance, 33, 260-78.

Kandori, M. 1992. Social norms and community enforcement. The Review of Economic Studies, 59(1), 63-80.

Kennedy, E. J. \& Lawton, L. (1998). Religiousness and business ethics. Journal of Business Ethics, 17(2), 163-75.

Kieser, A. (1989). Organizational, institutional and societal evolution: medieval craft guilds and the genesis of formal organizations. Administrative Science Quarterly, 34(4), 540-64.

Kohlberg, L. (1984). Essays on moral development Vol. 2. San Francisco, C.A.: Harper \& Row.

Kumar, A., Page, J. \& Spalt, O. (2011). Religious beliefs, gambling attitudes, and financial market outcomes. Journal of Financial Economics, 102(3), 671-708.

Larcker, D. F. \& Rusticus, T. O. (2010). On the use of instrumental variables in accounting research. Journal of Accounting and Economics, 49(3), 186-205.

Larraza-Kintana, M., Wiseman, R., Gómez-Mejía, L. R., \& Welbourne, T. 2007. Distinguishing between employment and compensation risk influences on perceived risk taking. Strategic Management Journal, 28(10), 1001-1019.

Lawler, E. E. (1981). Pay and organization development. Prentice Hall.

Lounsbury, M. (2007). A tale of two cities: Competing logics and practice variation in the professionalizing of mutual funds. Academy of Management Journal, 50(2), 289-307.

Lubatkin, M., Lane, P. J., Collin, S. \& Very, P. (2007). An embeddedness framing of governance and opportunism: towards a cross-nationally accomodating theory of agency. Journal of Organizational Behaviour, 28(1), 43-58.

Marquis, C. \& Battilana, J. (2009). Acting globally but thinking locally? The enduring influence of local communities on organizations. Research in Organizational Behavior, 29, 283302.

Marquis, C., Glynn, M. A. \& Davis, G. F. (2007). Community isomorphism and corporate social action. Academy of Management Review, 32:3, 925-45. 
Marquis, C. \& Lounsbury, M. (2007). Vive la resistance: Competing logics and the consolidation of US community banking. Academy of Management Journal, 50(4), 799-820.

Martin, G., Gómez-Mejía, L., \& Wiseman, R. (2013). Executive stock options as mixed gambles: revisiting the behavioral agency model. Academy of Management Journal, 56(2), 451472.

Martin, G., Gómez-Mejía, L. \& Wiseman, R. (2016). Bridging finance and behavioral scholarship on agent risk sharing and risk taking. The Academy of Management Perspectives, forthcoming.

Martin, G., Washburn, N., Makri, M. \& Gomez-Mejia, L. R. 2015. Not all risk taking is born equal: the behavioral agency model and CEO's perception of firm efficacy. Human Resource Management, 54(3), 483-98.

McGuire, S., Omer, T. \& Sharp, N. (2012). The impact of religion on financial reporting irregularities. Accounting Review, 87(2), 645-73.

Merriman, K. K. \& Sen, S. (2012) Incenting managers toward the triple bottom line: An agency and social norm perspective. Human Resource Management, 51(6), 851-871.

Miller, L. E. \& Grush, J. E. (1988). Improving predictions in expectancy theory research: effects of personality, expectancies and norms. Academy of Management Journal, 31(1), 107-22.

Montiel, I., Husted, B. W., \& Christmann, P. (2012). Using private management standard certification to reduce information asymmetries in corrupt environments, Strategic Management Journal, 33(9), 1103-1113.

Noussair, C. N., Trautmann, S. T., van de Kuilen, G. \& Vellekoop, N. (2013). Risk aversion and religion. Journal of Risk and Uncertainty, 47(2), 165-83.

Nyberg, A. J., Fulmer, I. S., Gerhart, B. \& Carpenter, M. A. (2010). Agency theory revisited: CEO returns and shareholder interest alignment. Academy of Management Journal, 53(5), 1029-49.

Oliver, C. (1997). Sustainable competitive advantage: Combining institutional and resourcebased views. Strategic Management Journal, 18(9), 697-713.

Ozment, S. (1991). Protestant: The Birth of a Revolution. New York, NY.: Doubleday.

Pappas, J. M. \& Flaherty, K. E. (2006). The moderating role of individual-difference variables in compensation research. Journal of Managerial Psychology, 21(1), 19-35.

Park, S., \& Sturman, M. C. (2016). Evaluating form and functionality of pay-for-performance plans: The relative incentive and sorting effects of merit pay, bonuses, and long-term incentives. Human Resource Management, 55(4), 697-719.

Pepper, A., Gore, J., \& Crossman, A. (2013). Are long-term incentive plans an effective and efficient way of motivating senior executives? Human Resource Management Journal, 23(1), 36-51.

Pirinsky, C. \& Wang, Q. (2006). Does corporate headquarters location matter for stock returns? Journal of Finance, 61(4), 1991-2015.

Porter, L. W. \& Lawler, E. E. (1968). Managerial Attitudes and Performance. Homewood, IL: Irwin.

Rajagopalan, N. \& Prescott, J. E. (1990). Determinants of top management compensation: Explaining the impact of economic, behavioral, and strategic constructs and the moderating effects of industry. Journal of Management, 16(3), 515-538.

Regnerus, M. D. (2003). Moral communities and adolescent delinquency: religious contexts and community social control. Sociological Quarterly, 44(4), 523-544. 
Ruefli, T. W., Collins, J. M. \& Lacugna, J. R. (1999). Risk measures in strategic management research: auld lang syne? Strategic Management Journal, 20(2), 167-94.

Sanders, W. G. (2001a). Behavioral responses of ceos to stock ownership and stock option pay. Academy of Management Journal, 44(3), 477-92.

Sanders, W.G. (2001b). Incentive alignment, CEO pay level, and firm performance: A case of "Heads I win, tails you lose"?. Human Resource Management, 40(2), 159-170.

Sanders, W. G. \& Hambrick, D. (2007). Swinging for the fences: the effects of CEO stock options on company risk taking and performance. Academy of Management Journal, 50(5), 1055-78.

Sauerwald, S., Lin, Z. J. \& Peng, M. W. (2016). Board social capital and excess CEO returns. Strategic Management Journal, 37(3), 498-520.

Schlesinger, L. A. (1983). The normative underpinnings of human resource strategy. Human Resource Management, 22(1-2), 83-95.

Schmidtke, J. M. (2007). The relationship between social norm consensus, perceived similarity, and observer reactions to coworker theft. Human Resource Management, 46(4), 561-582.

Scott, R. W. (1987). The adolescence of institutional theory. Administrative Science Quarterly, 32(4), 493-511.

Scott, W. R. (1995). Institutions and Organisations. Thousand Oaks, CA: Sage.

Seo, J. 2017. Board effectiveness and CEO pay: Board information processing capacity, monitoring complexity, and CEO pay-for-performance sensitivity. Human Resource Management, 56(3), 373-388.

Semadeni, M., Withers, M. C., \& Certo, S. T. (2014). The perils of endogeneity and instrumental variables in strategy research: Understanding through simulations. Strategic Management Journal, 35(7), 1070-1079.

Servaes, H. \& Tamayo, A. (2013). The impact of corporate social responsibility on firm value: The role of customer awareness. Management Science, 59(5), 1045-61.

Shleifer, A. \& Vishny, R. (1997). A Survey of corporate governance. Journal of Finance, 52(2), 737-83.

Shu, T., Sulaeman, J. \& Yeung, P. E. (2012). Local religious beliefs and mutual fund risk-taking behaviours. Management Science, 58(10), 1779-96.

Spence, M. (1973). Job market signaling. Quarterly Journal of Economics, 87:3, 355-74.

Stark, R. \& Bainbridge, W. S. 1996. Religion, deviance and social control. New York: Routledge.

Stock, J. H., Wright, J. H., \& Yogo, M. 2002. A survey of weak instruments and weak identification in generalized method of moments. Journal of Business \& Economic Statistics, 20(4): 518-529.

Sung, S. Y., Choi, J. N. \& Kang, S. C. (2017). Incentive pay and firm performance: Moderating roles of procedural justice climate and environmental turbulence. Human Resource Management, 56(2), 287-305.

Tajfel, H. (1978). Differentiation between social groups: Studies in the social psychology of intergroup relations. European Monographs in Social Psychology 14. London: Academic Press.

Thornton, P., Ocasio, W. \& Lounsbury, M. (2012). The institutional logics perspective. A new a approach to culture structure and process. Oxford University Press.

This article is protected by copyright. All rights reserved. 
Tosi, H., Katz, J. \& Gomez-Mejia, L. (1997). Disaggregating the agency contract: The effects of monitoring, incentive alignment, and term in office on agent decision making. Academy of Management Journal, 40(3), 584-602.

Tosi, H. L., Werner, S., Katz, J. P. \& Gomez-Mejia, L. R. (2000). How much does performance matter? A meta-analysis of CEO pay studies. Journal of Management, 26(2), 301-39.

Ulmer, J. T., Bader, C. \& Gault, M. (2008). Do moral communities play a role in criminal sentencing? Evidence from Pennsylvania. The Sociological Quarterly, 49(4), 737-68.

van Tubergen, F., te Grotenhuis, M. \& Ultee, W. (2005). Denomination, religious context, and suicide: neo-Durkheimian multilevel explanations tested with individual and contextual data. American Journal of Sociology, 111(3), 797-823.

Vroom, V. H. (1964). Work and motivation. New York: Wiley.

Weaver, G. R. \& Agle, B. R. (2002). Religiosity and ethical behavior in organizations: A symbolic interactionist perspective. Academy of Management Review, 27(1), 77-97.

Webb, E. J., Campbell, D.T., Schwartz, R.D., and Sechrest, L. (1966). Unobtrusive measures: Nonreactive research in the social sciences. Chicago, IL: Rand McNally.

Weber, M. (1905). The Protestant ethic and the spirit of capitalism. London, U.K.: Allen \& Unwin.

Westphal, J. D. \& Graebner, M. E. (2010). A matter of appearances: How corporate leaders manage the impressions of financial analysts about the conduct of their boards. Academy of Management Journal, 53(1), 15-44.

Westphal, J. D. \& Zajac, E. J. (1994). Substance and symbolism in CEOs' long term incentive plans. Administrative Science Quarterly, 39:367-390.

Westphal, J. D. \& Zajac, E. J. (1998). The symbolic management of stockholders: Corporate governance reforms and shareholder reactions. Administrative Science Quarterly, 43(1), 127-53.

Westphal, J. D. \& Zajac, E. J. (2013). A behavioral theory of corporate governance. Academy of Management Annals, 7(1), 607-61.

Wiseman, R., Cuevas-Rodriguez, G. \& Gómez-Mejía, L. R. (2012). Towards a social theory of agency. Journal of Management Studies, 49(1), 202-22.

Wiseman, R. M. \& Gómez-Mejía, L. R. 1998. A behavioral agency model of managerial risk taking. Academy of Management Review, 23(1), 133-53.

Wowak, A. \& Hambrick, D. C. (2010). A model of person-pay interaction: How executives vary in their responses to compensation arrangements. Strategic Management Journal, 31(8), 803-21. 
Table I. Descriptive Statistics and Correlations

\begin{tabular}{|c|c|c|c|c|c|c|c|c|c|c|c|c|c|c|c|c|c|c|c|c|c|}
\hline & & Mean & S.D. & 1 & 2 & 3 & 4 & 5 & 6 & 7 & 8 & 9 & 10 & 11 & 12 & 13 & 14 & 15 & 16 & 17 & 18 \\
\hline 1 & Tobin's Q & 1.84 & 1.28 & 1.00 & & & & & & & & & & & & & & & & & \\
\hline 2 & Delta & 5.33 & 1.49 & 0.28 & 1.00 & & & & & & & & & & & & & & & & \\
\hline 3 & Vega & 3.98 & 1.58 & 0.10 & 0.62 & 1.00 & & & & & & & & & & & & & & & \\
\hline 4 & Religious adherence & 0.54 & 0.12 & -0.05 & 0.06 & 0.02 & 1.00 & & & & & & & & & & & & & & \\
\hline 5 & Managerial discretion & 0.00 & 1.00 & 0.42 & 0.03 & -0.00 & -0.11 & 1.00 & & & & & & & & & & & & & \\
\hline 6 & Religious composition & 2.01 & 1.73 & 0.11 & 0.08 & 0.08 & 0.32 & 0.29 & 1.00 & & & & & & & & & & & & \\
\hline 7 & Political orientation & 1.74 & 1.27 & 0.00 & 0.11 & 0.13 & 0.04 & 0.08 & 0.32 & 1.00 & & & & & & & & & & & \\
\hline 8 & Education & 0.22 & 0.08 & 0.11 & 0.15 & 0.16 & 0.09 & 0.26 & 0.28 & 0.52 & 1.00 & & & & & & & & & & \\
\hline 9 & Minority & 0.30 & 0.15 & -0.01 & 0.09 & 0.10 & -0.09 & 0.06 & 0.04 & 0.44 & 0.15 & 1.00 & & & & & & & & & \\
\hline 10 & Past stock returns & 0.18 & 0.72 & 0.29 & 0.15 & -0.02 & -0.01 & 0.06 & 0.02 & 0.01 & 0.02 & 0.01 & 1.00 & & & & & & & & \\
\hline 11 & Investments & 0.08 & 0.08 & 0.12 & 0.00 & -0.05 & 0.00 & -0.15 & -0.09 & -0.13 & -0.09 & -0.06 & -0.03 & 1.00 & & & & & & & \\
\hline 12 & Firm age & 2.99 & 0.74 & -0.19 & 0.00 & 0.18 & 0.07 & -0.31 & -0.07 & 0.04 & -0.07 & -0.09 & -0.07 & -0.09 & 1.00 & & & & & & \\
\hline 13 & Firm size & 7.60 & 1.79 & -0.28 & 0.41 & 0.51 & 0.09 & -0.35 & -0.05 & 0.16 & 0.07 & 0.13 & -0.06 & -0.19 & 0.40 & 1.00 & & & & & \\
\hline 14 & R\&D & 0.03 & 0.07 & 0.35 & -0.06 & -0.03 & -0.11 & 0.75 & 0.21 & 0.00 & 0.14 & 0.01 & 0.02 & -0.01 & -0.18 & -0.31 & 1.00 & & & & \\
\hline 15 & Return volatility & 0.10 & 0.06 & 0.17 & -0.15 & -0.28 & -0.11 & 0.36 & 0.07 & -0.06 & 0.04 & 0.02 & 0.17 & 0.03 & -0.35 & -0.43 & 0.30 & 1.00 & & & \\
\hline 16 & Leverage & 0.18 & 0.18 & -0.17 & -0.06 & 0.01 & 0.01 & -0.30 & -0.12 & -0.07 & -0.06 & -0.02 & -0.05 & 0.14 & 0.11 & 0.12 & -0.13 & -0.03 & 1.00 & & \\
\hline 17 & Advertising & 0.01 & 0.04 & 0.13 & 0.03 & 0.05 & 0.02 & 0.02 & 0.03 & 0.08 & 0.04 & 0.01 & 0.02 & 0.03 & -0.02 & -0.07 & -0.02 & 0.02 & -0.04 & 1.00 & \\
\hline 18 & Analyst coverage & 1.86 & 1.05 & 0.11 & 0.27 & 0.29 & -0.02 & -0.01 & -0.02 & 0.00 & 0.03 & 0.03 & -0.03 & 0.02 & 0.07 & 0.30 & -0.01 & -0.16 & -0.07 & 0.02 & 1.00 \\
\hline
\end{tabular}

This article is protected by copyright. All rights reserved. 
Table II. The Relationship Between CEO Equity Incentives and Firm Value

\begin{tabular}{lcc|cc}
\hline \hline \multicolumn{1}{c|}{} & \multicolumn{2}{c}{$\begin{array}{c}\text { Panel A. Instrumental variable } \\
\text { estimation }\end{array}$} & $\begin{array}{c}\text { Panel B. Changes around option } \\
\text { expensing regulation }\end{array}$ \\
\hline & Coefficient & Standard errors & Coefficient & Standard errors \\
\hline Delta & $0.52 * * *$ & $(0.05)$ & $0.51 * * *$ & $(0.09)$ \\
Vega & $-0.13 * * *$ & $(0.04)$ & $-0.30 * * *$ & $(0.09)$ \\
Past stock returns & $0.23 * * *$ & $(0.04)$ & $0.27 * * *$ & $(0.05)$ \\
Investments & $0.02 * *$ & $(0.01)$ & 0.01 & $(0.04)$ \\
Firm age & $-0.24 * * *$ & $(0.06)$ & 0.24 & $(0.31)$ \\
Firm size & $-0.79 * * *$ & $(0.08)$ & $-0.54 * *$ & $(0.24)$ \\
R\&D & $0.07 * *$ & $(0.03)$ & $0.23 * *$ & $(0.09)$ \\
Return volatility & -0.02 & $(0.02)$ & -0.01 & $(0.06)$ \\
Leverage & -0.04 & $(0.04)$ & -0.11 & $(0.07)$ \\
Advertising & 0.02 & $(0.03)$ & $0.38 * *$ & $(0.19)$ \\
Analyst coverage & $0.09 * * *$ & $(0.02)$ & 0.11 & $(0.07)$ \\
\hline Obs. & & 18,647 & & 735 \\
Adjusted R & & 0.72 & & 0.29 \\
\hline \hline
\end{tabular}

Model in Panel A was estimated using an instrumental variable approach with firm- and year-fixed effects included and with asymptotic standard errors adjusted for heteroskedasticity and clustering at firm level. Model in Panel B was estimated using OLS with the industry fixed effects based on the three-digit SIC codes and with asymptotic standard errors adjusted for heteroskedasticity. All $p$-values are for two-tailed tests.

$* p<0.1$.

$* * p<0.05$.

$* * * p<0.01$. 
Table III. The Effect of Local Religious Social Norms on the CEO Equity Incentives-Firm Value Relationship

\begin{tabular}{|c|c|c|c|c|c|c|c|c|}
\hline & \multicolumn{2}{|c|}{ Model 1} & \multicolumn{2}{|c|}{ Model 2} & \multicolumn{2}{|c|}{ Model 3} & \multicolumn{2}{|c|}{ Model 4} \\
\hline & Coefficient & Standard error & Coefficient & Standard error & Coefficient & Standard error & Coefficient & Standard error \\
\hline Delta & & & $0.46^{* * *}$ & $(0.03)$ & $0.46^{* * *}$ & $(0.03)$ & $0.46^{* * *}$ & $(0.03)$ \\
\hline Vega & & & $-0.08 * * *$ & $(0.02)$ & $-0.08 * * *$ & $(0.02)$ & $-0.09 * * *$ & $(0.02)$ \\
\hline Religious adherence & & & & & 0.01 & $(0.03)$ & 0.04 & $(0.03)$ \\
\hline Delta $\times$ Religious adherence & & & & & & & $-0.09 * * *$ & $(0.02)$ \\
\hline Vega $\times$ Religious adherence & & & & & & & $0.04 * *$ & $(0.02)$ \\
\hline Past stock returns & $0.30 * * *$ & $(0.04)$ & $0.24 * * *$ & $(0.04)$ & $0.23 * * *$ & $(0.04)$ & $0.23 * * *$ & $(0.04)$ \\
\hline Investments & $0.04 * * *$ & $(0.01)$ & $0.02 * *$ & $(0.01)$ & $0.02 * *$ & $(0.01)$ & $0.02 * * *$ & $(0.01)$ \\
\hline Firm age & $-0.40 * * *$ & $(0.07)$ & $-0.25 * * *$ & $(0.06)$ & $-0.24 * * *$ & $(0.06)$ & $-0.23 * * *$ & $(0.06)$ \\
\hline Firm size & $-0.55 * * *$ & $(0.07)$ & $-0.79 * * *$ & $(0.08)$ & $-0.81 * * *$ & $(0.07)$ & $-0.81 * * *$ & $(0.08)$ \\
\hline R\&D & $0.07 *$ & $(0.04)$ & $0.07 * *$ & $(0.03)$ & $0.08 * *$ & $(0.03)$ & $0.08 * *$ & $(0.03)$ \\
\hline Return volatility & -0.03 & $(0.02)$ & -0.01 & $(0.02)$ & -0.02 & $(0.02)$ & -0.02 & $(0.02)$ \\
\hline Leverage & -0.08 & $(0.05)$ & -0.04 & $(0.04)$ & -0.04 & $(0.04)$ & -0.04 & $(0.04)$ \\
\hline Advertising & 0.02 & $(0.03)$ & 0.02 & $(0.03)$ & 0.02 & $(0.03)$ & 0.02 & $(0.03)$ \\
\hline Analyst coverage & $0.12 * * *$ & $(0.02)$ & $0.09 * * *$ & $(0.02)$ & $0.09 * * *$ & $(0.02)$ & $0.09 * * *$ & $(0.02)$ \\
\hline Obs. & & 18,647 & & 18,647 & & 18,647 & & 18,647 \\
\hline Adjusted $\mathrm{R}^{2}$ & & 0.69 & & 0.72 & & 0.72 & & 0.73 \\
\hline
\end{tabular}

The models were estimated using OLS with both firm- and year-fixed effects included and with asymptotic standard errors adjusted for heteroskedasticity and

clustering at firm level. County-level controls (i.e., Religious composition, Political orientation, Education, and Minority) were included both interacted with Delta and

Vega and separately in Models 3 and 4, but not reported for brevity. All $p$-values are for two-tailed tests.

$* p<0.1$.

$* * p<0.05$.

$* * * p<0.01$

This article is protected by copyright. All rights reserved. 
Table IV. The Effect of Local Religious Social Norms on the CEO Equity Incentives-Firm Value Relationship: The Role of Managerial Discretion

\begin{tabular}{|c|c|c|c|c|}
\hline & \multicolumn{2}{|c|}{ High managerial discretion } & \multicolumn{2}{|c|}{ Low managerial discretion } \\
\hline & Coefficient & Standard error & Coefficient & Standard error \\
\hline Delta & $0.68^{* * *}$ & $(0.05)$ & $0.22 * * *$ & $(0.02)$ \\
\hline Vega & $-0.13 * * *$ & $(0.04)$ & $-0.05 * * *$ & $(0.02)$ \\
\hline Religious adherence & -0.04 & $(0.06)$ & 0.05 & $(0.03)$ \\
\hline Delta $\times$ Religious adherence & $-0.12 * * *$ & $(0.04)$ & $-0.03^{\wedge}$ & $(0.02)$ \\
\hline Vega $\times$ Religious adherence & $0.05^{\wedge}$ & $(0.03)$ & 0.01 & $(0.02)$ \\
\hline Past stock returns & $0.29^{* * *}$ & $(0.05)$ & $0.12 * * *$ & $(0.02)$ \\
\hline Investments & 0.001 & $(0.01)$ & $0.06 * * *$ & $(0.01)$ \\
\hline Firm age & $-0.36 * * *$ & $(0.10)$ & 0.02 & $(0.04)$ \\
\hline Firm size & $-1.20 * * *$ & $(0.12)$ & $-0.43 * * *$ & $(0.05)$ \\
\hline $\mathrm{R} \& \mathrm{D}$ & $0.08 * *$ & $(0.04)$ & $0.04 *$ & $(0.02)$ \\
\hline Return volatility & -0.05 & $(0.03)$ & $-0.02 *$ & $(0.01)$ \\
\hline Leverage & 0.01 & $(0.05)$ & $-0.09 * * *$ & $(0.02)$ \\
\hline Advertising & 0.02 & $(0.04)$ & 0.01 & $(0.03)$ \\
\hline Analyst coverage & $0.10 * * *$ & $(0.03)$ & $0.07 * * *$ & $(0.01)$ \\
\hline Obs. & & 9,323 & & 9,323 \\
\hline Adjusted $\mathrm{R}^{2}$ & & 0.72 & & 0.77 \\
\hline
\end{tabular}

The models were estimated using OLS with both firm- and year-fixed effects included and with asymptotic standard errors adjusted for heteroskedasticity and clustering at firm level. County-level controls (i.e., Religious composition, Political orientation, Education, and Minority) were included both interacted with Delta and Vega and separately, but not reported for brevity.

$* p<0.1$, two-tail

$* * p<0.05$, two-tail

$* * * p<0.01$, two-tail

$\wedge p<0.1$, one-tail 
Figure I. Conceptual Model

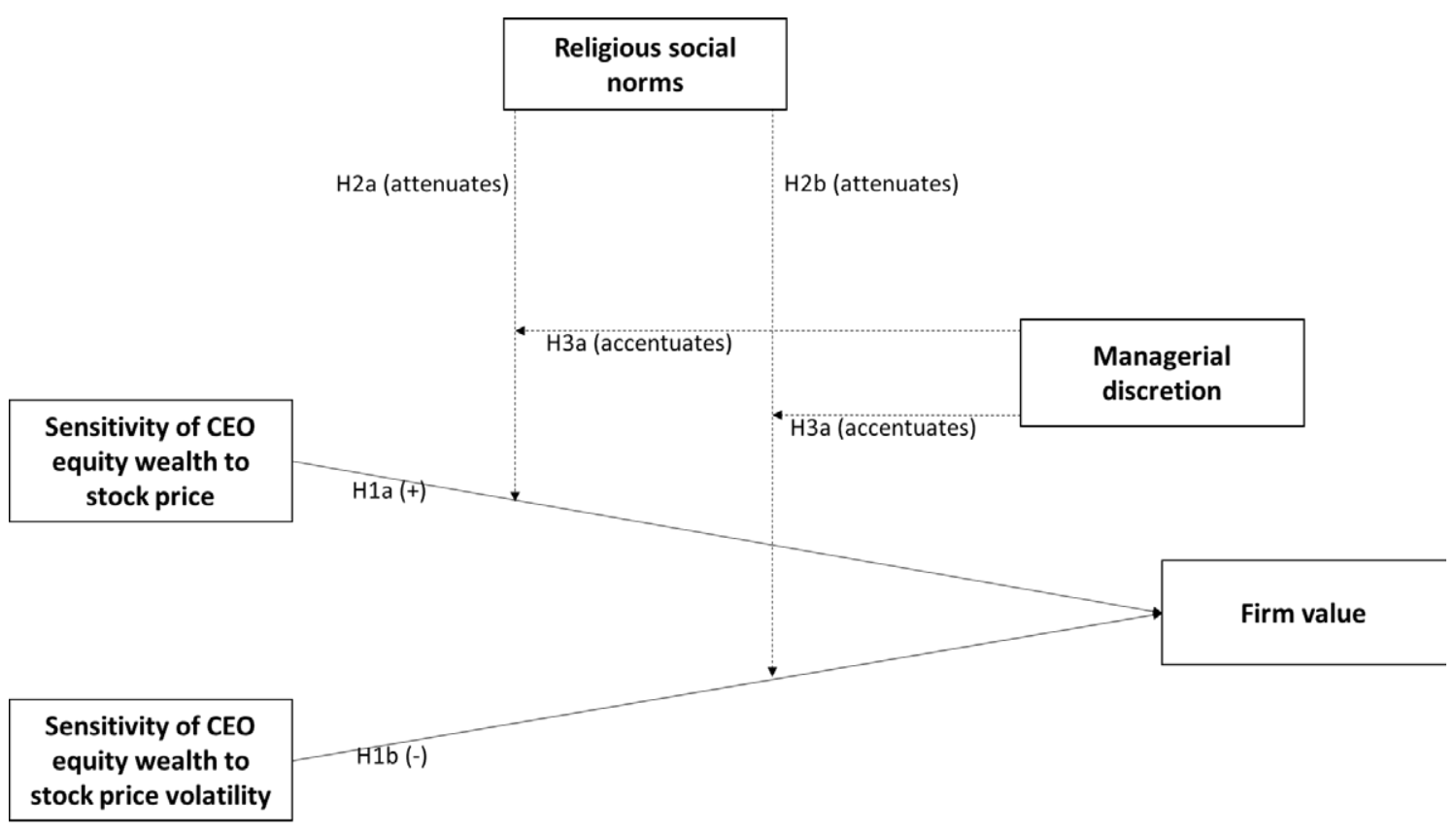

This article is protected by copyright. All rights reserved. 


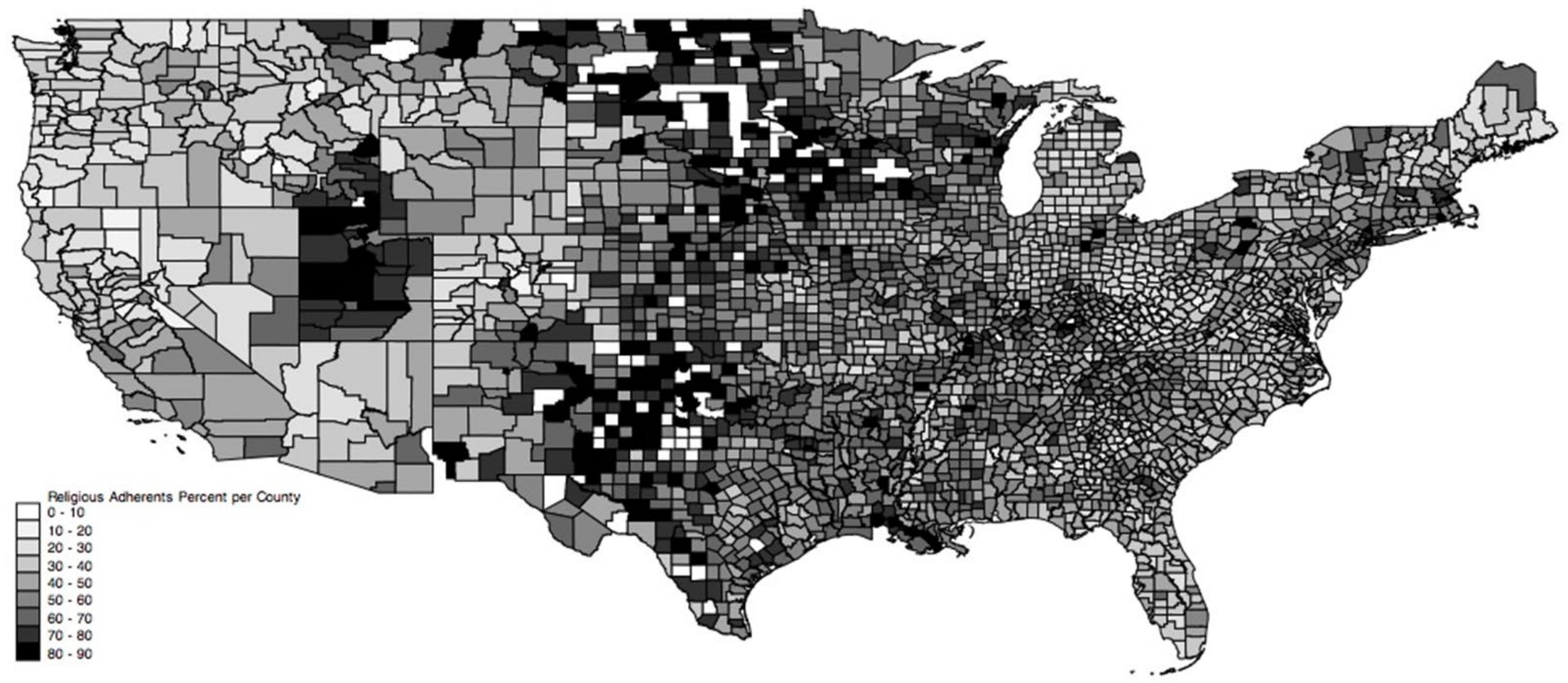


Figure III. The Moderating Effect of the Strength of Local Religious Social Norms on the Relationship Between CEO Delta and Firm Value

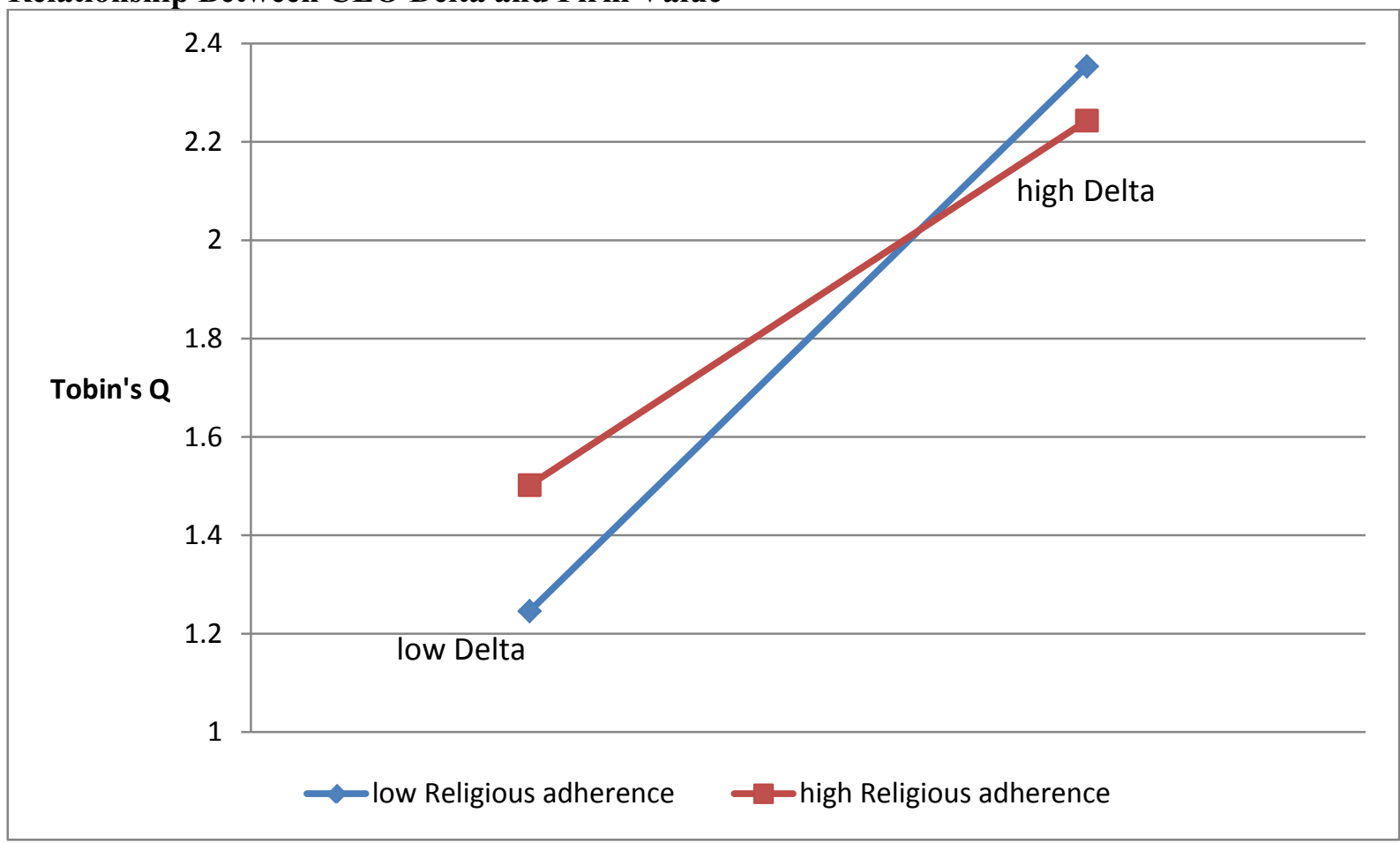

Low (high) Delta denotes Delta one standard deviation below (above) its sample mean. Low (high) Religious adherence denotes Religious adherence one standard deviation below (above) its sample mean.

Figure IV. The Moderating Effect of the Strength of Local Religious Social Norms on the Relationship Between CEO Vega and Firm Value

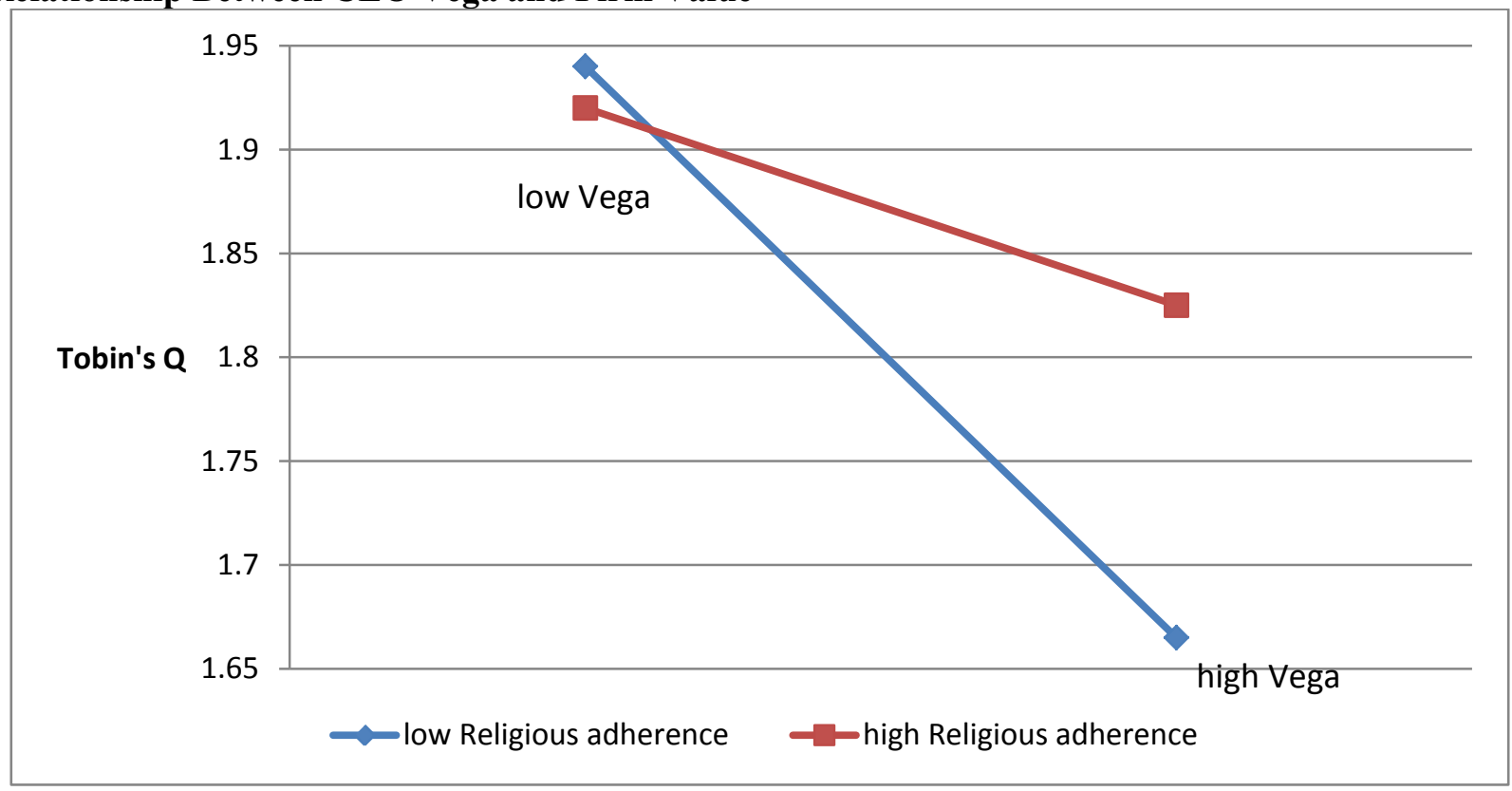

Low (high) Vega denotes Vega one standard deviation below (above) its sample mean. Low (high) Religious adherence denotes Religious adherence one standard deviation below (above) its sample mean.

This article is protected by copyright. All rights reserved. 


\section{NOTES}

i Higher stock price volatility means there is a greater probability that, at some point in the future, the stock price will exceed the option exercise price (the price at which the executive can buy the shares). Thus, the value of stock options is positively related to stock price volatility. Executive stock options are typically granted to executives with an exercise price that approximates the price of the firm's shares at the date of granting, in order to create incentives for the executive to increase the stock price. Once vested, executives can realize the intrinsic value of the option if the market price of shares exceeds the exercise price.

ii Similar to prior work (e.g., Callen \& Fang, 2015; Hilary \& Hui, 2009), the underlying assumption for our measure of religious adherence is that the strength of religious social norms is stronger in counties with a larger proportion of religious adherents. Here we also note that there is strong support for this intuition in the literature on the relationship between religious adherence and a wide range of attitudes and behaviors (Boone, 2013; Regnerus, 2003; Ulmer, Bader, \& Gault, 2008). ARDA — our source of data on religious adherence — reports numbers of religious adherents at the county level. While county-level analysis is consistent with the literature (e.g., Hilary \& Hui, 2009; Shu et al., 2012), we recognize that there could be some degree of variation in religious adherence within counties. Any such variation would introduce a random noise in our measure which would bias against finding significant results for the hypothesized effects of religious adherence on the equity incentives-firm value relationship. 
iv Similar to prior studies (e.g., Kumar et al., 2011; Shu et al., 2012), firms in our sample tend to be headquartered in states with relatively large concentrations of Catholic populations, such as California and New York. Nonetheless, there is a substantial degree of variation in both religious adherence and religious composition across the counties in these two states. Further, by including firm-fixed effects in our analysis we control for potential headquarters' location effects on our results.

v Controlling for firm-fixed effects is particularly importantly, given that there could be unobservable firm-specific attributes which could impact firm value, which are not captured by firm industry affiliation. To emphasize this point, we re-estimated our baseline model with industry effects based on 4-digit SIC codes instead of firm-fixed effects. The (untabulated) results show that the model with industry fixed effects exhibits a sharp reduction in its explanatory power compared to the model with firm-fixed effects: the (untabulated) adjusted $\mathrm{R}^{2}$ for the model with industry effects is 0.51 , whereas the adjusted $\mathrm{R}^{2}$ for the model with firm-fixed effects is 0.73 (see Table 3 ). Hence, we view firm-fixed effect model specification as a superior empirical framework for exploring our research question compared to the model with industry effects. These variables explain a significant portion of variation in local religious norms in our sample. Furthermore, after controlling for local religious adherence, it is unlikely that these local demographic attributes are correlated with the propensity of religiously motivated CEOs joining firms headquartered in the area. Hence, these local demographic attributes provide suitable instruments for our purposes (Stock, Wright, \& Yogo, 2002; Larcker \& Rusticus, 2010; Semadeni, Withers, \& Certo, 2014). 


\section{University Library}

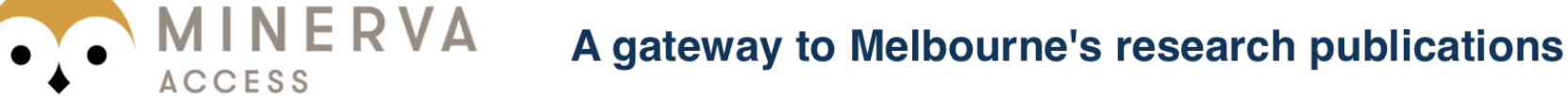

Minerva Access is the Institutional Repository of The University of Melbourne

Author/s:

Zolotoy, L;O'Sullivan, D;Martin, G

Title:

The Social Context of Compensation Design: Social Norms and the Impact of Equity Incentives

Date:

2018

Citation:

Zolotoy, L., O'Sullivan, D. \& Martin, G. (2018). The Social Context of Compensation Design: Social Norms and the Impact of Equity Incentives. Human Resource Management, 57 (5), pp.1233-1250. https://doi.org/10.1002/hrm.21897.

Persistent Link:

http://hdl.handle.net/11343/283611 